\title{
Novel Bioactive Extraction and Nano-Encapsulation
}

\author{
Shaba Noore ${ }^{1,2} \oplus$, Navin Kumar Rastogi ${ }^{3}$, Colm $\mathrm{O}^{\prime}$ Donnell $^{2}$ and Brijesh Tiwari ${ }^{1,2, *}$ \\ 1 Department of Food Chemistry \& Technology, Teagasc Food Research Centre, \\ Ashtown, D15 DY05 Dublin, Ireland; shaba.noore@ucdconnect.ie \\ 2 School of Biosystems and Food Engineering, University College Dublin, \\ Belfield, D04 V1W8 Dublin, Ireland; colm.odonnell@ucd.ie \\ 3 Department of Food Engineering, CSIR-Central Food Technological Research Institute, \\ Mysuru 570020, India; nkrastogi@cftri.res.in \\ * Correspondence: Brijesh.Tiwari@teagasc.ie
}

check for updates

Citation: Noore, S.; Rastogi, N.K.; O'Donnell, C.; Tiwari, B. Novel Bioactive Extraction and Nano-Encapsulation. Encyclopedia 2021, 1, 632-664. https:/ / doi.org/10.3390/encyclopedia1030052

Academic Editors: Raffaele Barretta,

Ramesh Agarwal, Krzysztof Kamil

Żur and Giuseppe Ruta

Received: 11 June 2021

Accepted: 20 July 2021

Published: 26 July 2021

Publisher's Note: MDPI stays neutral with regard to jurisdictional claims in published maps and institutional affiliations.

Copyright: (c) 2021 by the authors. Licensee MDPI, Basel, Switzerland. This article is an open access article distributed under the terms and conditions of the Creative Commons Attribution (CC BY) license (https:// creativecommons.org/licenses/by/ $4.0 /)$.
Definition: An extraction technology works on the principle of two consecutive steps that involves mixture of solute with solvent and the movement of soluble compounds from the cell into the solvent and its consequent diffusion and extraction. The conventional extraction techniques are mostly based on the use of mild/high temperatures $\left(50-90^{\circ} \mathrm{C}\right)$ that can cause thermal degradation, are dependent on the mass transfer rate, being reflected on long extraction times, high costs, low extraction efficiency, with consequent low extraction yields. Due to these disadvantages, it is of interest to develop non-thermal extraction methods, such as microwave, ultrasounds, supercritical fluids (mostly using carbon dioxide, $\mathrm{SC}-\mathrm{CO}_{2}$ ), and high hydrostatic pressure-assisted extractions which works on the phenomena of minimum heat exposure with reduced processing time, thereby minimizing the loss of bioactive compounds during extraction. Further, to improve the stability of these extracted compounds, nano-encapsulation is required. Nano-encapsulation is a process which forms a thin layer of protection against environmental degradation and retains the nutritional and functional qualities of bioactive compounds in nano-scale level capsules by employing fats, starches, dextrins, alginates, protein and lipid materials as encapsulation materials.

Keywords: non-thermal extraction; bioactive compounds; nanoencapsulation; ultrasound; cold plasma; high-pressure processing; supercritical extraction; pulse electric field

\section{Introduction}

Bioactive compounds also known as secondary metabolites are widely present in plant matrix and over the past few decades, several in vitro and in vivo reports including epidemiological, and cohort studies provide evidence that consumption of plant-based food provides protection against several diseases. These bioactive extracts are also capable of treating chronic diseases including cancer, cardiovascular and diabetes mellitus (DM). Nutraceutical and pharmaceutical sectors use these extracts to develop functional foodand plant-based medicines, which have a potential to cure and deliver health benefits. According to the World Health Organization (WHO), about $80 \%$ of the global population depends on natural medicines. The initial steps followed to use these active compounds from plant matrix are extraction followed by pharmacological testing, isolation, characterization and clinical evaluation. Figure 1 represents a detailed flow chart of bioactive compound extraction from plant matrix.

The quality and yield of the bioactive compounds depend on two important factors: (a) the method opted for its extraction, (b) its extraction parameters including plant matrix type, solvent used, time and temperature. The most conventional method employed for bioactive extraction is Soxhlet extraction, maceration and hydro-distillation. Although, these techniques are commercially employed, but excessive use of solvents and longer processing times are the downsides of these technologies. Presently, demand for sustainable, chemical-free, advanced extraction processes with enhanced overall yield 
of bioactive compounds, also known as "green techniques", which include ultrasoundassisted, enzyme-assisted, microwave-assisted, pulsed electric field-assisted, high-pressure processing, supercritical fluid and pressurized liquid extraction processes are gaining attention. Treating the plant matrix with these green technologies helps in breaking the cell structure, which allows the bioactive compound to leach or rinse out from the cell wall through solvents; as a result, it enhanced extraction yield. Further, purification of the extracted bioactive poses another technological challenge as each of these compounds has a unique molecular structure depending on their type, source and biological activity. The extracted compounds can be further purified, employing super critical $\mathrm{CO}_{2}$ isolation, by addition of a co-solvent including ethanol, water to isolate the respective bioactive compound efficiently at an optimized temperature and pressure [1]. In addition, it is essential to protect the extracted bioactive compound post extraction and purification, as these compounds are highly sensitive to environment exposure including moisture and high temperature (sensitive under heat, light, oxygen). Therefore, protection techniques such as nanoencapsulation are used to ensure that biological activity of these compounds is preserved until they reach and perform their function at the targeted location in the human body.

Encapsulation plays a vital role in protecting the bioactive compounds from getting degraded. At present, there are two kinds of encapsulation including microencapsulation and nanoencapsulation. The reason why nanoencapsulation is preferred over microencapsulation is due to its nano-scale size, as the smaller the size of the capsules, the higher their bioavailability and their release can be modified and controlled in a better way comparatively. Nanoencapsulation provides a protective shield around bioactive compounds. It is a system where a suitable nano-carrier, resistant to enzymatic degradation especially in gastrointestinal tract including chitosan, zein, and alginate, are widely used to encapsulate bioactive compounds employing several delivery methods including association colloids, nano-particles, nano-emulsions, nano-fibers/nano-tubes, nano-laminates. The selection encapsulation method is based on two main factors: (a) nature of the core material; (b) nature of wall material including wall material size, thickness, solubility, permeability and its rate of delivery. Basically, these techniques are classified into three main genres including chemical (emulsion and interfacial polymerization), physical-chemical (emulsification and coacervation) and physical-mechanical methods (spray-drying/spray-cooling/spraycongealing/prilling, freeze-drying, electrodynamic methods and extrusion) [2]. However, in certain cases, combinations of these techniques are practiced as in the case of emulsification; first using homogenization, the emulsions are prepared and later converted to dry powder state using spray-drying and/or freeze-drying techniques [3]. Reports indicate that about $80-90 \%$ of flavor encapsulation is done using spray-drying, while $5-10 \%$ by spray-chilling, $2-3 \%$ by melt extrusion and $~ 2 \%$ by melt injection [4]. Castro et al. [5] reported electro-spinning encapsulation as a heat-free technique to encapsulate fragrance and flavor, which is extremely promising for heat-sensitive compounds.

To recapitulate, this chapter provides a comprehensive summary on several aspects of bioactive extraction using non-thermal technologies and its nanoencapsulation. A brief description on nano-carriers employed for encapsulation is also discussed along with the detailed description of their application in food systems. Various opportunities and future challenges are also outlined. 

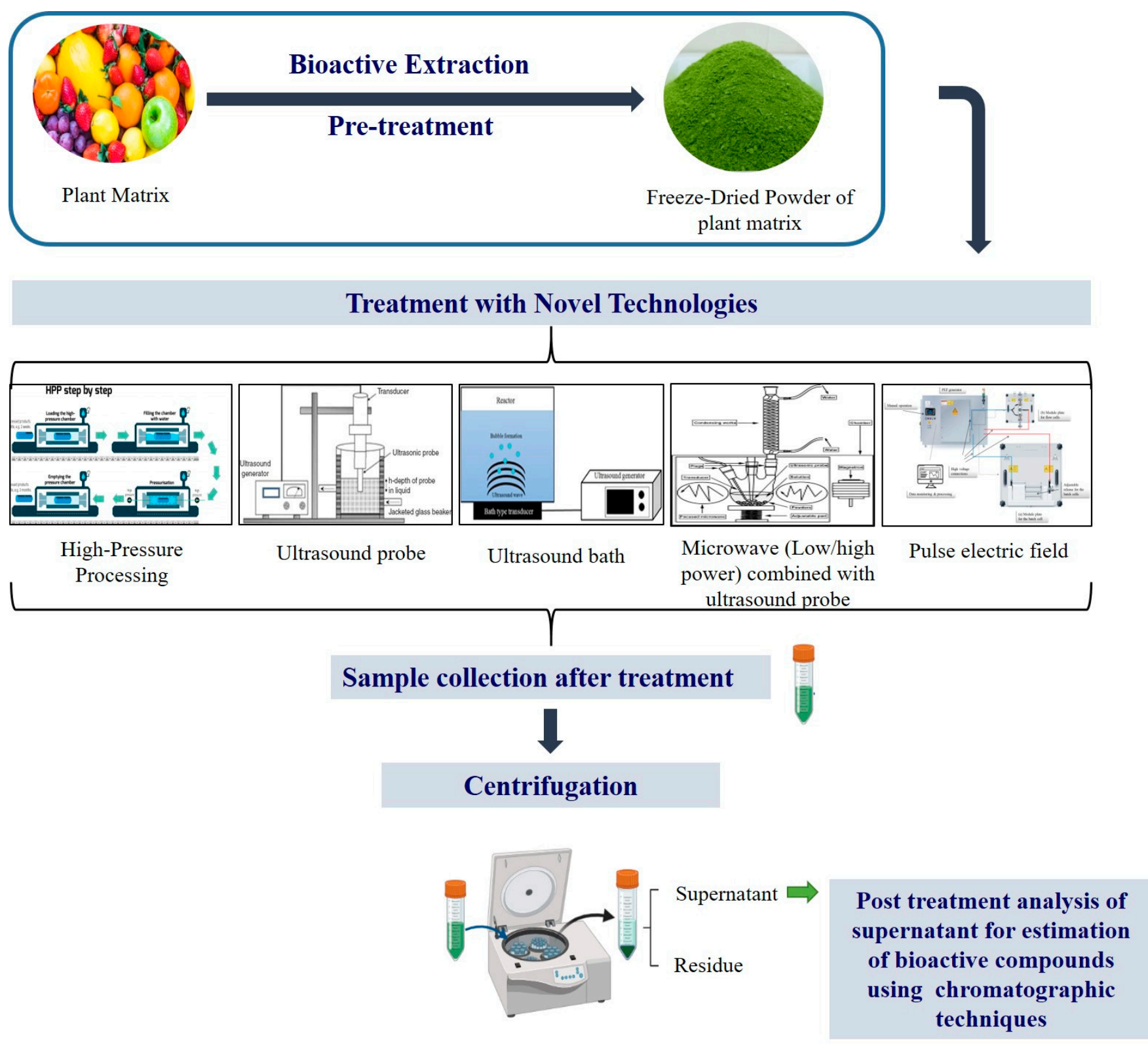

Figure 1. Illustration for the extraction of bioactive compound using novel strategies.

\section{Bioactive Compounds from Plant Materials}

Ever since the beginning of human existence, plants have always been a boon for living a healthy life, as they not only provide a healthy environment to live, but most importantly, they provide food and bioactive compounds for medicinal use. In the beginning, plants and plant-related foods were used as a source of food and nutrition; later, their medicinal properties were discovered, which were able to cure diseases. Vinatoru et al. [6] reported that Egyptian papyruses extracted oil from coriander and caster and used it in several applications including medicine, cosmetics and as preservatives. Further, Paulsen et al. [7] reported that, during the Roman and Greek era, herbal plants were used by several therapeutics. According to literature [8], bioactive compounds comprise three different categories including terpenes/terpenoids, alkaloids and phenolics. Basically, the chemical structure of these three categories differs, as shown in Figure 2, and maximum bioactive compounds extracted from plant matrix belong to the terpenoids family.

Additionally, these compounds are classified based on their clinical and toxicological attributes as follows. 


\subsection{Glycosides}

Glycosides are generally bonded by a mono/oligosaccharide or uronic acids. The part that is bonded with saccharide is called glycone and the other part is termed as aglycone, which consists of pentacyclic triterpenoids/tetracyclic steroids. The major subgroups of glycosides include cardiac glycosides, saponins, anthraquinone, glucosinolates and cyanogenics. Moreover, flavonoids commonly exist as glycosides. These glycosides are broken down in colon post ingestion; however, hydrophobic glycosides tend to get absorbed by the muscle cells. Cardiac glycosides are generally found in plants such as the Scrophulariaceae family, specifically in Digitalis purpura and in Convallaria majalis from Convallariaceae family. Additionally, cyanogenic glycosides can be found in the Prunus spp. of Rosaceae family as well as saponin, a bitter-tasting compound is found in glycosides. These saponin glycosides, found widely in the Liliaceas family (Narthesium ossifragum), is comprised of bigger molecules attached to hydrophilic glycone as well as hydrophobic aglycone, which creates forming quality, and thus it is used in the production of soap/detergent. Saponins also play an important role in modulating immune system and reducing blood sugar level. Besides, anthraquinone glycosids found in the Rumex crispus and Rheum spp. of polygonaceae family help in electrolyte secretion as well as induction of water and peristalisis in colon. Moreover, flavonoids are comprised of tri-ring at the center of the structure and proanthocyanidin is an oligomer in flavonoids. These two groups of compounds can also exist as glycosides. These are responsible for liberating antioxidant properties, inflammation and anti-carcinogenic activities. They are also responsible for the pigments in a wide range of plants. In addition, isoflavones are considered as a nutritional supplement type of bioactive molecules produced almost exclusively by the Fabaceae (Leguminosae or bean) family. They are basically a precise group of molecules, popularly known as phytochemicals, natively found in legumes and spices such as red clove. They are also considered as antioxidant molecules, as they help in the reduction of damage caused by oxygen in the body. Additionally, it plays a vital role in fighting against cancer cells.

\subsection{Tannins}

Tannins are widely found in plants, especially in the Fagaceae and Polygonaseae family. They are basically divided into two types, including condensed and hydrolysable tannins. Condensed groups of tannins are comprised of bigger polymers of flavonoids, while hydrolysable groups of tannins are clusters of monosaccharide (glucose) bonded with various derivatives of catechin. Tannin molecules tend to indiscriminately bind with protein molecules. Larger groups of tannins are used as medicine for treating skin bleeding, diarrhea and transudates.

\subsection{Mono/Sesqui-Terpenoids and Phenylpropanoids}

Synthesis of terpenoids takes place by a penta-carbon isoprene. In case of monoterpenoids, two units of isoprene are found, while in sespui-terpenoids there are three units of isoprene. They are popularly known for their low molecular weight and wide range of categories (more than 25,000). However, phenylpropanoids comprises group of molecules where the basic carbon skeleton starts from nine and more, with strong odor, flavors and are volatile in nature. Generally, these compounds are commonly called volatile oils, widely found in the Lamiaceae family. It is used as an herbal medication including antineoplastic, antiviral and antibacterial effects. Besides, it also helps in gastrointestinal stimulation. In addition, diterpenoids are lipophilic non-volatile (odorless) compound and is a cluster of 4 units of isoprene with a strong flavor. It is widely found in various plants including Coffee arabica and popularly known for its antioxidant qualities. 
<smiles>C1CCN2CC3CC(CN4CCCCC34)C2C1</smiles>

a1<smiles>Cc1ccc(C(C)C)c(O)c1</smiles>

b<smiles>[R9]C1CCC2(C)C(CCC3(C)C2CC=C2C4CC(C)(C)CCC4(C(=O)O)CCC23C)C1(C)C</smiles>

d<smiles>CCCC(O)/C=C/C=C/C=C/C=C/C=C/CCCO</smiles>
f<smiles>CN1CCCC1c1cccnc1</smiles>

a2

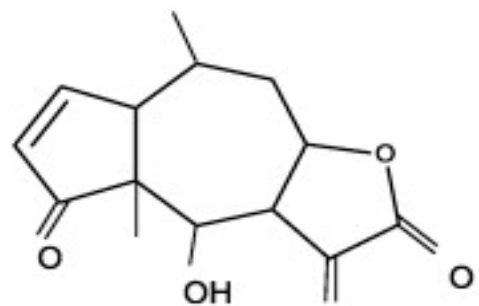

C<smiles>O=c1c(O)c(-c2ccc(O)c(O)c2)oc2cc(O)cc(O)c12</smiles>

$\mathbf{e}$<smiles>Cc1cc(O)c2c(c1)C(=O)c1cc(C)cc(O)c1C2=O</smiles>

g

Figure 2. Basic structures of plant bioactive compounds alkaloids (a1,a2), monoterpenes (b), sesqueterpenes (c), triterpenes, saponins, steroids (d), flavonoids (e), polyacetylenes (f), polyketides (g) (Adopted with permission from Wink et al. [9].

\subsection{Resins}

Resins are composite mixtures which comprise both volatile as well as non-volatile attribute compounds; as well, they are comprised of a lipid soluble group of compounds. Non-volatile resins consist of diterpenoid and triterpenoid compounds, while volatile resins are equipped with mono/sesquiterpenoids. These resins are broadly found in herbaceous plants and are popularly known for their wound healing and antimicrobial properties.

\subsection{Alkaloids}

Alkaloids, a bitter-tasting and nitrogen-holding compound is a heterocyclic with limited spread in the plant kingdom. The Solanaceae family, including Atropa belladonna, 
Datura spp as well as Hyoscyamus niger, consists of tropane alkaloids with anticholinergic properties. It is widely used for reducing muscle pain. Besides, pyrrolizidine alkaloids belong to the Asteraceae and Boraginaceae family, especially in Senecio spp. It comprises of a wide range of application including treating cancer cells, stimulating bone marrow leucocytes and myocardial contractility. In addition, methylxanthine alkaloids are distributed in Coffee arabia as well as Theobroma cacao.

\subsection{Proteins}

Plant proteins have gained significant popularity in the field of food and medicinal sectors as they are a major source of nutrient for humans and animals. The Euphorbiaceae family as well as Fabaceae and lentils are known to contain a high content of protein.

\section{Novel Strategies for the Extraction of Bioactive Compounds from Plant Matrix}

\subsection{Individual Strategies}

\subsubsection{Ultrasound-Assisted Extraction (UAE)}

Bioactive extraction from plant matrix using ultrasound has been widely employed over the past few decades [10]. It works on the principal of mechanical wave with a frequency ranging from $20 \mathrm{kHz}$ to $100 \mathrm{MHz}$, which passes through a medium at a cycle of expansion and compression. In the case of liquid medium, cavitation bubbles are formed, at high acoustic pressure [11]. This phenomenon is known as "acoustic cavitation" as it enhances the extraction yield as the high shear force is induced by the cavitation, which leads to mass transfer of bioactive compounds by turbulent mixing and acoustic flow $[12,13]$. Ultrasound (US) extraction works on four basic parameters including ultrasound power, ultrasonic intensity, mode of working (e.g., non-pulsed/pulsed) and acoustic energy density [14]. In addition, it is divided into two different set-ups such as the US-bath and US-probe systems. In the case of an ultrasound bath system, the ultrasonic transducer array is placed below at the bottom of the extraction bath, which can also be attached at the side walls of the US-bath or inside the bath as a transducer array box. The transducer array box can be placed at any direction as per the requirement based on sample matrix. Whereas, in the case of the US-probe system, the probe is bonded with the transducer, which is submersed in liquid medium, enabling direct distribution of US waves, hence resulting in minimum loss of US energy. In addition, US intensity is an important factor affecting the yield of bioactive extraction, hence, it is important to consider the type of US employed, especially the probe diameter and the design of transducer employed as per the requirement [15].

Over the past few years, US has evolved, as from the fixed US power system, now it is possible to adjust the acoustic power. Most probe-type US devices usually control the amplitude of the probe vibration, and some of them can apply busters to increase its maximum amplitude. Alexandru et al. [16] developed a continuous US system for scale-up extraction to industrial level. In this system, a huge capacity of samples can be extracted continuously by feeding into a relatively small tank with multi-horn ultrasonic reactor. Elevated amplitude/intensity can enhance the sonochemistry but it leads to degradation of the transducer, which leads to increased agitation and reduced cavitation level. Hence, high amplitude/intensity is not essential to improve the extraction efficiency of cavitation level. However, the sample with high viscosity needs high amplitude as the high viscous samples tend to decrease the effect of sonication or cavitation [17]. Therefore, to achieve the required level of cavitation, it is necessary to enhance the level of amplitude [18]. Further, enhanced US frequency results in reduction in cavitation level. US develops cavitation bubbles, which take time to be initiated after the compression-rarefaction cycles. At high frequencies, it is challenging to produce acoustic cavitation, as the cycles of compressionrarefaction are too short to allow the growth of the cavitation bubbles. Therefore, higher amplitude and intensity of ultrasonic devices are needed to produce acoustic cavitation at high frequency [19]. Apart from physical properties, chemical properties including solubility and stability of the target compound in selected solvent also play an essential 
role in the extraction yield and efficiency of bioactive compounds from plant matric using US. Parameters like time and temperature are also considered to influence the level of extraction $[20,21]$.

Several bioactive compounds have been effectively extracted using US from a plantbased matrix (fruits, vegetables/their by-products) [22-24]. Pan et al. [25] extracted bioactive compounds from pomegranate peel using conventional and US extraction techniques. The results indicate that a continuous US-pulsed system enhanced the level of antioxidant extraction to $22-24 \%$ and reduced the extraction time to $90 \%$. Due to the enhanced extraction yield and reduced time as well as energy consumption, US is considered as an alternate and green technology for the extraction of bioactive compounds. Apart from fruits and vegetables, US is also employed to extracted bioactive compounds from medicinal herbs, spices and oleaginous seeds [26-29].

\subsubsection{Microwave-Assisted Extraction (MAE)}

Over the past few years, microwave (MW) has gained popularity in the extraction of bioactive compounds from plant-based matrix [30-33]. It works on the principal of electromagnetic waves and frequencies, mostly $915 \mathrm{MHz}$ and $2450 \mathrm{MHz}$ frequencies employed for industrial and domestic applications. The mechanism behind this technique is that MW works on heating effect, which results in higher extraction temperature, causing faster mass transfer [34]. MW has the tendency to penetrate inside the sample matrix causing interaction in polar components, thus causing direct/bulk heating effect to the solvent and the sample matrix [12]. Further, this direct/bulk heating by MW also helps in the reduction of time and solvent used especially in industrial level extraction. Moreover, in MW extraction, the direct heating enters inside the matrix and increases local temperature and pressure, leaching out the target bioactive compounds from the sample matrix to the solvent solution. Two different setups are available for MW extraction: (a) open system, (b) closed system, where the pressure can be adjusted, e.g., increase or set at atmospheric level, respectively. The closed system MW extraction is carried out in a sealed vessel with constant MW heating, at controlled pressure and temperature. This closed system helps in reaching higher temperatures than the open system, as the amplified pressure in the closed vessel increases the boiling point of the extraction solvent [35]. Although high temperature and pressure lead to efficient, high and fast extraction yield with less solvent consumption, they also escalate the safety risks (Figure 3). In addition, this particular system is limited to certain bioactive compounds as maximum compounds are heat-sensitive and tends to degrade at elevated temperature, thus, the open system is promoted widely [36].

MW extraction depends on several ranges of factors including microwave power, frequency, exposure time, moisture content, particle size of sample matrix, type and composition of solvent, dilution ratio, extraction temperature, extraction pressure and the number of extraction cycles. The detailed description of these factors has been reported by some reviews. The most critical factor is selection of extraction solvents as its solubility with sample matrix, its dielectric constant and dissipation plays a major role in extraction process. Solvents with higher dielectric constant like water and polar solvents can store more microwave energy than nonpolar solvents, thus water and polar solvents are reported to be better for MW extraction [37]. Besides, the dissipation factor, which converts electromagnetic energy into heat, is considered a significant factor for MW extraction. Ajila et al. [38] reported that solvents including ethanol and methanol, which contain a higher dissipation factor, are better solvents than water in the extraction of phenolics. Although, water possesses a high dielectric constant as compared to ethanol and methanol, but due to its low dissipation factor, it fails to heat up the sample matrix in depth. Therefore, for this reason, combination of solvents (water with ethanol or methanol), which contains high dielectric constant as well as a high dissipation factor, can be used to enhance the extraction efficiency. 


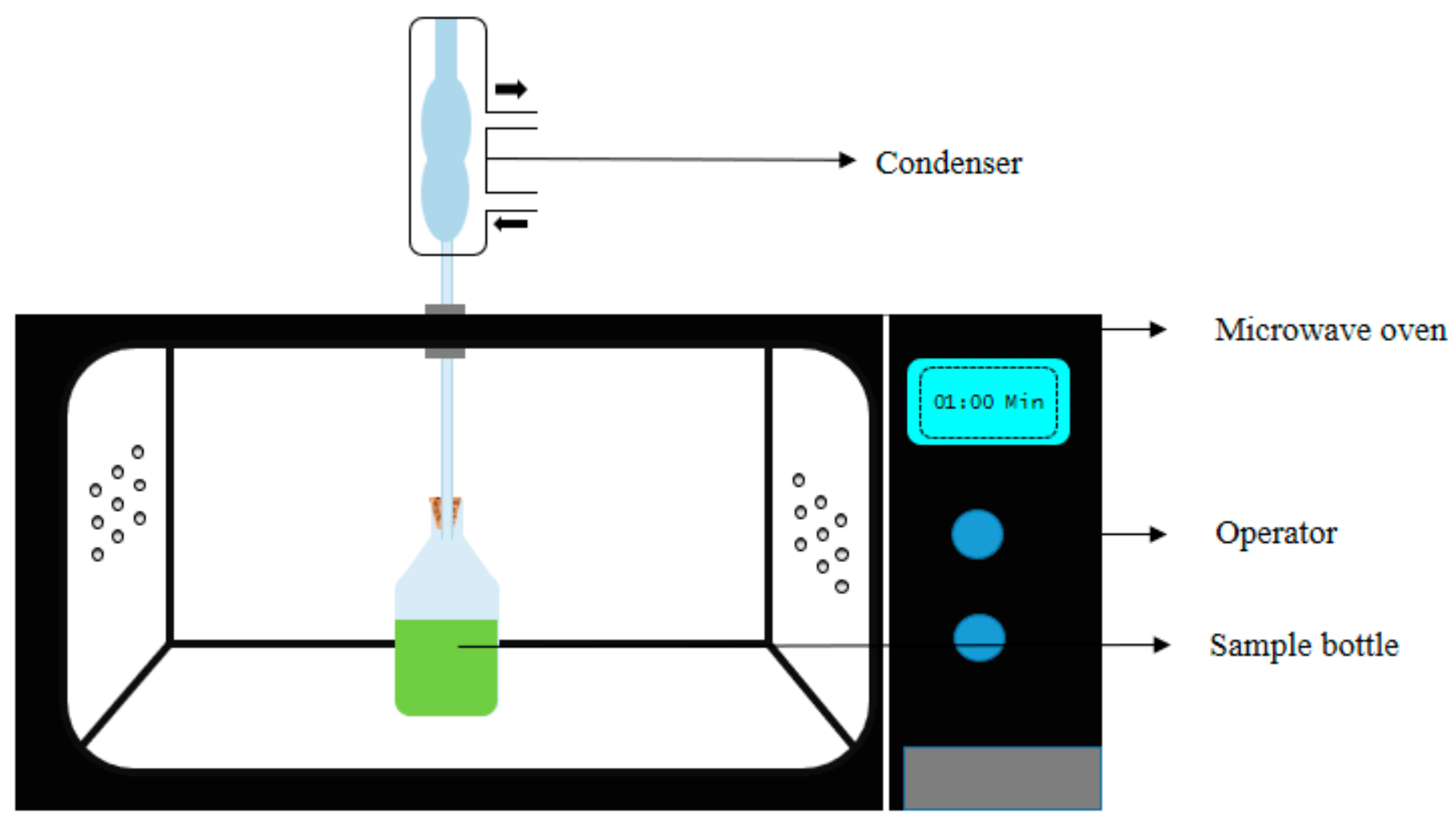

Figure 3. Schematic representation of the microwave-assisted extraction apparatus.

MW extraction comprises a wide range of advantages over conventional extraction techniques including reduction in extraction time, solvent used and extraction cost with a significant level of enhancement in extracted compounds. Shu et al. [39] extracted ginsenosides from ginseng root using MW extraction techniques for $15 \mathrm{~min}$ and resulted in a higher yield compared to conventional extraction, which took $10 \mathrm{~h}$ to complete. Dhobi et al. [40] extracted flavolignin and silybinin from Silybum marianum employing MW extraction and results revealed that the extraction efficiency was enhanced to $60 \%$ compared with the conventional solvent extraction methods. Similarly, Asghari et al. [41] extracted cinnamaldehyde and tannin from some medicinal Asian plants and their results reflected in a quicker and easier technique compared with conventional extraction techniques.

\subsubsection{Enzyme-Assisted Extraction (EAE)}

EAE is considered as one of the most efficient, eco-friendly, and non-thermal extraction strategies over conventional extraction techniques. It has been employed by several food industries for the extraction of various bioactive compounds saponin, carotenoid, anthocyanin and many more [41]. Incorporation of certain enzymes including pectinases, cellulases and hemicellulases during extraction can significantly enhance extraction efficiency/yield of bioactive compounds by the principal of degradation in cell wall and membrane interiority $[42,43]$. In this technique, adequate knowledge about the catalytic specificity and its mode of action is necessary to acquire as well as to know its optimum conditions suitable for the enzymes to act on the plant matrixes. In order to use enzymes efficiently for EAE, it is essential to understand their catalytic specificity and mode of action, as well as investigate optimal conditions and which enzyme or enzyme combination is more suitable for the raw materials [44]. Several significant factors including enzyme composition and concentration, type of extraction solvent, solid-to-liquid ratio, enzyme/substrate ratio, $\mathrm{pH}$, extraction temperature and time play a vital role in activation of enzyme reaction and extraction of bioactive compounds [12,45]. 
Temperature is one of the important factors influencing the rate of extraction, but excessive increase of temperature may also inactivate enzymes. Moreover, a wide range of compounds are heat-sensitive, and therefore require mild temperature throughout the extraction process [46]. Furthermore, $\mathrm{pH}$ is one of the major reaction conditions where the enzyme gets activated and stated to degrade the cells of the sample matrix. The optimum $\mathrm{pH}$ for each enzyme has already been reported; however, it may vary depending upon the matrix used and reaction conditions applied [19,47]. Enhancement in ratio between enzyme/substrate tends to improve catalytic reaction rate, but due to this amount of enzyme used, increases, which results in increased extraction cost. Further, the solvent used for the extraction may not be suitable for the enzymes used in the extraction process, for instance, several enzymes used for extraction of bioactive compounds from plant matrix are active in water, which may be not be active at higher concentrations of solvents including methanol and ethanol. Many bioactive compounds are highly soluble in concentrated methanol and ethanol; therefore, in such cases, major concern needs to be given to the selection of enzyme and its reaction conditions to achieve the desired extraction yield.

EAE is broadly employed for the extraction of bioactive components from a wide range of plant matrix including flavonoid from the peel of citrus, fructans from Dasylirion wheeleri, curcumin from turmeric, anthocyanin from beetroot, total phenolics from pomegranate peels and Cassia fistula pods, polysaccharide from seaweed and Cedrela sinensis, lycopene from tomato tissues and fatty acids from microalgae [48-53].

\subsubsection{Pulse Electric Field-Assisted Extraction (PEF)}

Over the years, PEF has become one of the most promising non-thermal and costeffective bioactive extraction techniques to extract compounds used by the nutraceutical and pharmaceutical sector. The concept of PEF began in 1999 by a researcher named Ganeva and co-workers. They treated beer yeast with $2.75 \mathrm{kV} / \mathrm{cm}$ pulse electric power and kept it for macerating for $5 \mathrm{~h}$ for the extraction of protein. Further, they found that, after treating the sample with PEF, the dissolution enhanced, which was reflected in a significant increment in protein extraction. This gave a light of hope to the other researchers, as PEF has the ability to improve the mass transfer rate through cell membrane. Based on this belief, many researchers carried out several experiments for the extraction of bioactive compounds employing PEF and found that this non-thermal technology, when compared with several other extraction techniques, indicated shorter treatment time (some microseconds) with higher extraction yield [54]. In addition, this technique can easily be employed at the industrial level for continuous flow of extraction. The system is equipped with a high-voltage pulse generator, a sample holding chamber and a controller. The treatment chamber contains two electrodes with a gap. One of the electrodes is connected to the pulse generator and the other is earthed (Figure 4). Before treating the sample, it is subjected to fine powder, followed by agitation in the selected solvent. After agitation, the sample is pooled in the treatment chamber, led by the treatment parameter settings such as pulse number or pulse width $(\mu \mathrm{s})$, electrode voltage $(24 \mathrm{kV})$, energy input $(\mathrm{kJ})$, frequency $(\mathrm{Hz})$. Usually, at high electric voltage, the extraction is higher, but in the case of some compounds such as polysaccharides, it tends to decompose, which results in low extraction yield [54]. Hence, it is important to decide the parameters of the extraction based on the targeted compounds. In addition to this factor, including solvent conductivity, polarity, solubility with the target compounds also plays a vital role in the extraction process. Generally, conductivity, solubility of the solvent and dilution ratio of solvent to solute as well as pulse duration/width is directly propositioning to the extraction yield. However, if we further increase these conditions beyond the requirement, then it tends to reflect negative results as when a high amount of electric pulse is applied, the targeted compound may also start to degrade, which can reduce the extraction yield and thus selection of the correct solvent, and operation factors are extremely significant [55]. Bioactive compounds including protein, saccharides, calcium and others are easily extracted using PEF. 
(a)

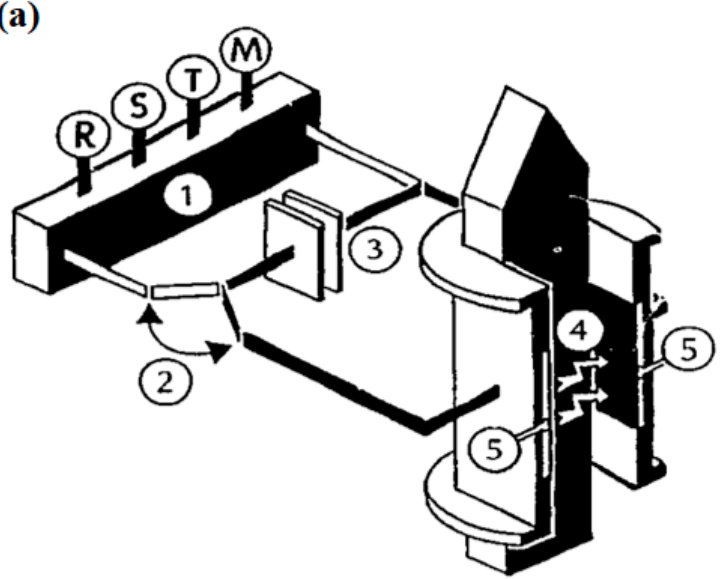

(c)

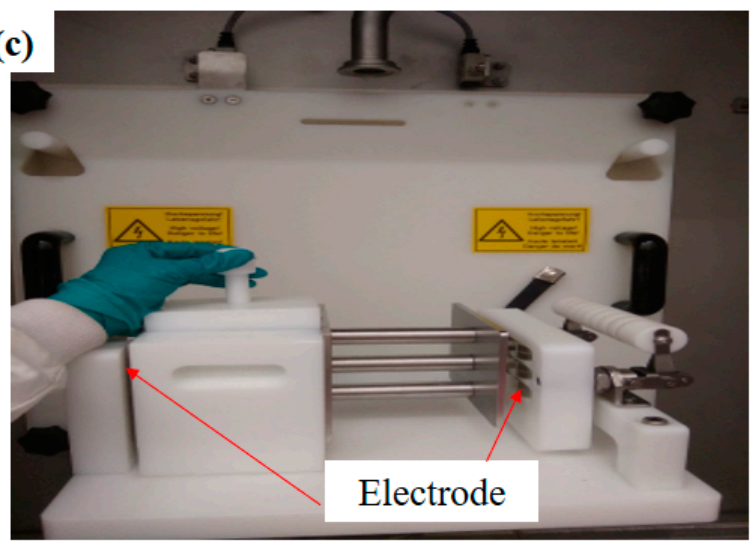

(b)

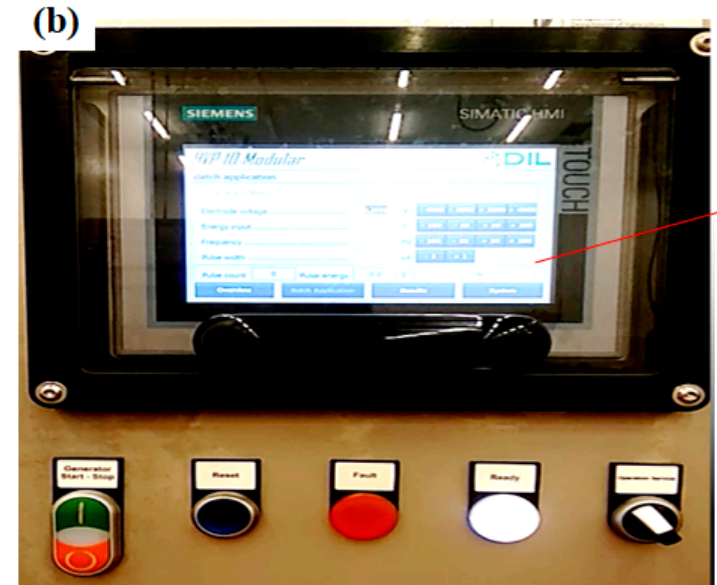

Pulse Electric field

control panel

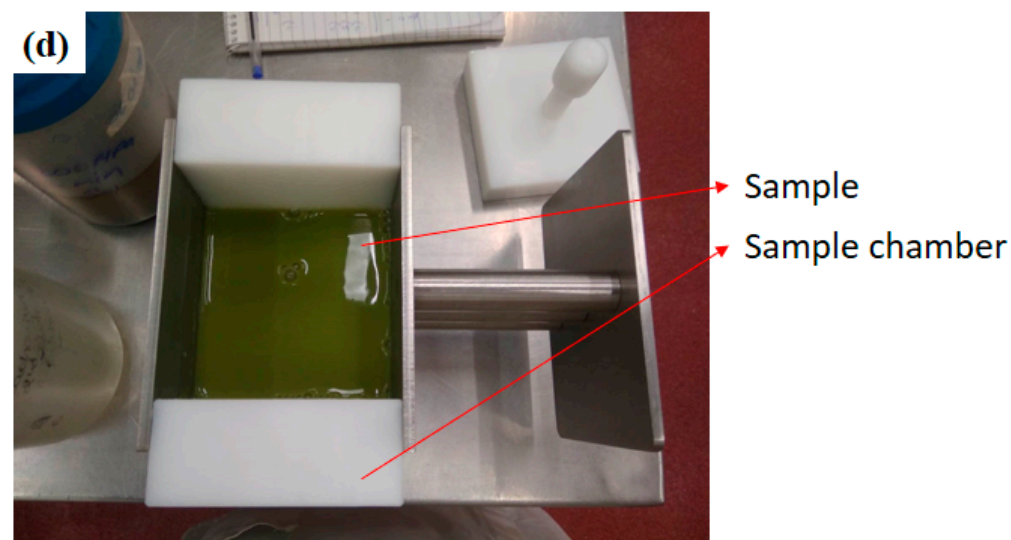

Figure 4. Simplified schematic diagram of PEF (a) 1. High-voltage generator; 2. Switch; 3. Capacitor; 4. Medium; 5. Electrodes: and R, S, T, M, connector points for the main supply; (b) control panel of PEF; (c) Pulse electric field electrodes and treatment chamber; (d) sample chamber with sample. (Modified and adopted with permission from Knorr et al. [56].

\subsubsection{Moderate Pressure Application}

Supercritical-Assisted Extraction (SFE)

Supercritical fluid extraction is employed over the conventional extraction method, as the solvents used in this technique differ in physicochemical properties including density, diffusivity, viscosity and dielectric constant. In addition, these properties play a critical role in the extraction process, as these supercritical fluids are low viscous and high in diffusivity, thus movement of solvent through the plant matrix becomes easy and results in a faster rate of exchange. There are a wide range of compounds/solvents including carbon dioxide, ethane, ethane, methanol, nitrous oxide, n-butene, n-pentane, sulphur hexafluoride and water used as supercritical fluid. However, carbon dioxide is considered the most promising fluid for the extraction of bioactive compounds due to few reasons, such as, it is harmless to the environment and human health, its favorable critical temperature $\left(31.2^{\circ} \mathrm{C}\right)$ which helps to extract heat-sensitive compounds easily and the extracted compounds are preserved from oxidation when exposed in air [57]. As carbon dioxide is at room temperature in its gaseous state of matter, it is easily eliminated after the extraction is completed, and the achieved compounds are left as solvent-free extraction.

Basically, the SFE process of extraction is divided into two main categories: (a) solubilization of bioactive compounds in the extraction fluid; (b) its separation into the fluid of supercritical. Throughout the extraction, the fluid passed through the cells of plant matrix, solubilizing the compounds present in cell membrane, thereby resulting in the extraction chamber with the solubilized target compound. Further, by release of pressure and change in temperature, the fluid becomes separated from the compound and, as a result, the pure form of the compound is extracted. Brunner et al. [58] reported that the initial step of 
extraction (solubilization) takes place in several stages. In the beginning, the plant matrix absorbs the supercritical fluid, which leads to swelling of its cellular membrane followed by expansion in intracellular passages, which results in mass transfer, and thus the solubilized compounds moved from inner cell membrane to outer surface, and lastly, it is separated from the fluid. In order to optimize the treatment conditions of the SCFE technique, intense knowledge in thermodynamic (solubility and selectivity) and kinetic data (mass transfer coefficients) is essential. The kinetic illustration of SFE is achieved by extraction curve graph, illustrated in Figure 5, which educates about the extraction yield subjected to extraction time $(\mathrm{t})$. Overall extraction curve (OEC) is divided into three different time phases of mass transfer, (a) constant extraction rate (CER) and the phase is called tCER, wherein the compound is packed inside the solute, therefore leading to convection mass transfer; (b) falling extraction rate (FER) and the phase is called tFER, wherein convection is combined with diffusion mechanism as the external lipid layer of the cell membrane fails to remain intact; (c) diffusion control (DC) and the phase is called tDC. In tDC, the lipid layer is completely corroded and the diffusion starts inside the plant matrix; hence, maximum extraction is achieved [59-61]. Moreover, the evaluation of the extraction curve was carried out using spline model, where the extraction takes place from constant phase of extraction to falling extraction rate and then finally to diffusion rate [62]. In addition, tCER tFER and tDC (in min) indicate the time span of CER, FER and DC respectively. As the sample passes through these phases, the bioactive compounds are extracted with the increase in time at a specific pressure and temperature. At higher temperature with low pressure (approximately $20 \mathrm{MPa}$ ), extraction yield is amplified. However, the rise in temperature reduced the characteristics of compounds extracted.

Due to the promising outcome of SFE techniques, it provides a wide range of application in the food, cosmetics and pharmaceutical sectors, as it helps in the extraction of flavors, analgesics and anti-inflammatory drugs. It is also helpful for the development of drugs for the treatment of chronic diseases such as stroke, cancer and Alzheimer $[63,64]$.

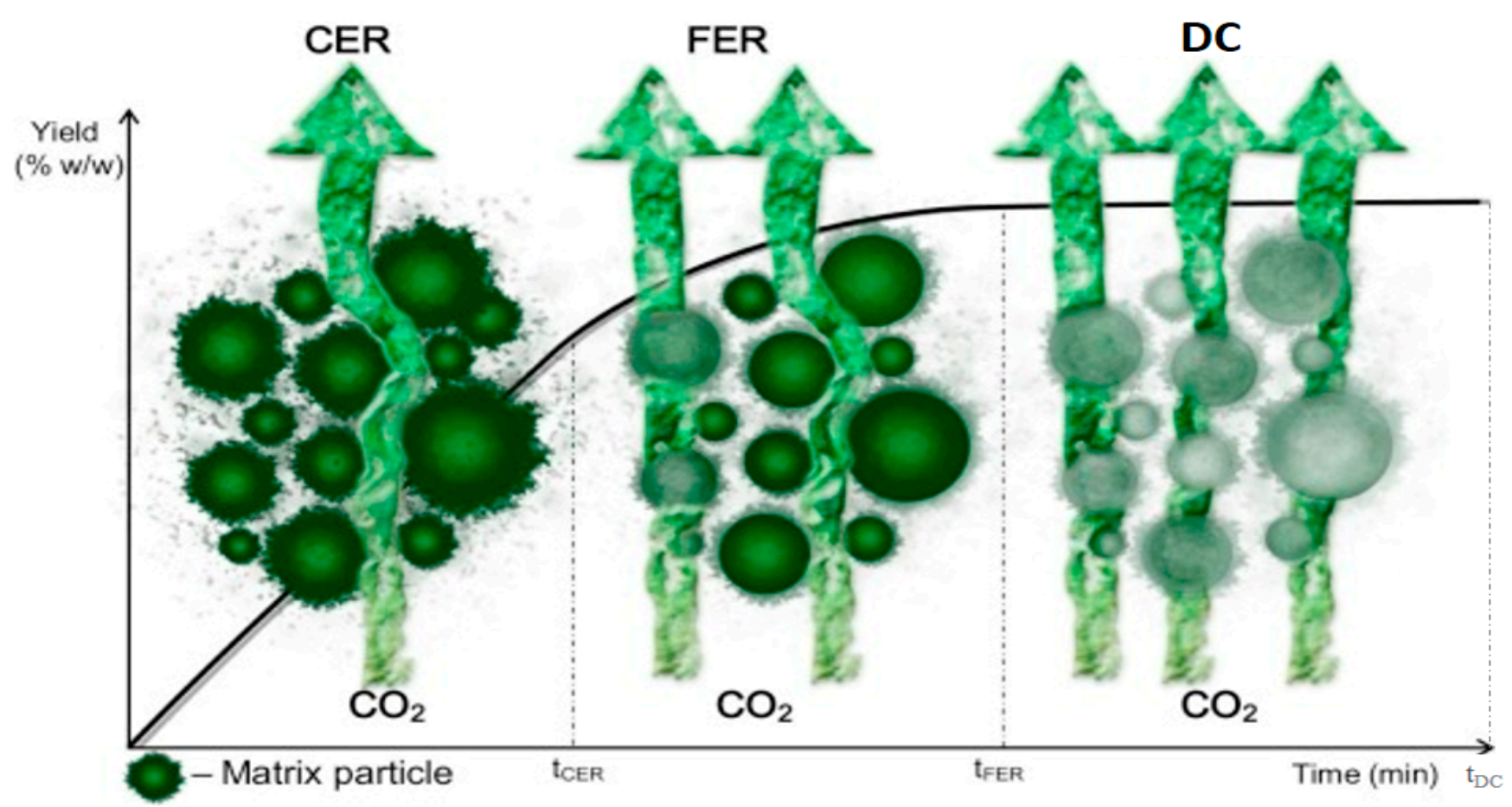

Figure 5. Graphical representation of mass transfer of bioactive compounds from cell membrane to solvent (modified and adopted with permission from Rui et al. [62]). 
3.1.6. High-Pressure Application

High Hydrostatic Pressure-Assisted Extraction (HHPAE)

This novel extraction technique works on the principle of combination of pressure (100 to $500 \mathrm{MPa})$ and temperature $\left(20-50^{\circ} \mathrm{C}\right.$ ) which results in enhancements to mass transfer rate. According to the US Food and Drug Administration, this technique possesses environmentally friendly attributes, and hence has gained popularity in a wide range of food and nutraceutical sectors [65]. The mild temperature employed in HHPAE has positively reflected promising results for the extraction of heat-sensitive bioactive compounds [65-67]. HHPAE improved the rate of extraction by enhancing mass transfer rate by rupturing the cell membrane and organelles at minimum consumption of solvent and time [68-71]. HHPAE was first reported by a German researcher, Knorr et al., 1999 [72], for the extraction of caffeine from coffee seeds. Further, in 2004, Sanchez-Moreno et al. [73] stabilized a protocol for the extraction of carotenoid from tomato at 100-400 MPa. Over the last few years, HHPAE has evolved rapidly for the extraction of these bioactive compounds. Firstly, the plant matrix is dried and milled followed by sieving (40-60 mesh) to secure an even particle size of sample for the extraction. Secondly, an appropriate solvent is selected based on the solubility of the target bioactive compound in that solvent. Lastly, fine plant powder is incorporated in solvent in a sterile polyethylene bag. The bag is further vacuum-sealed and kept inside the pressure vessels equipped with a pressure and temperature regulator (thermocouple) attached at the top and bottom of the vessel to maintain the desired temperature (Figure 6). Further, the pressure vessel is filled with water to create a pressure by a pressure pump attached to the vessel. Post extraction, the mixture is filtered and the solid particles are removed. The filtered extract is further centrifuged at 4000 to $8000 \mathrm{rpm}$ for $10-15 \mathrm{~min}$. Post centrifugation, the supernatant is collected and passed through a $0.45 \mu \mathrm{m}$ membrane for characterization and quantification analysis of the targeted compound [74,75]. Liu et al. [76] studied the effect of high-pressure treatment on cell membrane of ginseng roots using scanning electron microscopy (SEM), and the results reveal that the damaged/ruptured cell membrane was clearly identified in the high-pressure-treated sample compared to untreated samples, and therefore it is concluded that HHPAE enhances the extraction efficiency of bioactive compounds in plant matrix. The efficiency of the extractions is based on a few important parameters including pressure applied, time/temperature combination, dilution ratio of solvent and solute, particle size of solute and polarity of the solvent used [77]. Solvents with similar polarity to the targeted compounds significantly give better extraction yield.

HHPAE has been proven to be promising for enhancing the diffusion capacity of the solvent inside the plant matrix by rupturing the cell membrane, which results in improved permeability, hence increased extraction yield [78]. It also breaks the hydrophobic bonds and denatures the protein molecules, thereby making the extraction better $[79,80]$. Moreover, based on dissolution mass transfer theory (mass transfer rate $=$ pressure $/$ resistance of mass transfer), the dissolution is higher in HHPAE [81]. The more the pressure/temperature $\left(30^{\circ} \mathrm{C}, 50^{\circ} \mathrm{C}, 70{ }^{\circ} \mathrm{C}\right)$ is applied, the more is the solvent dissolution to cell, which enables the compounds to leach out the membrane. In addition, pressure-holding time helps in maintaining the equilibrium of solvent between inside and outside of the cell membrane. However, long pressure-holding time may damage the biological activities of the plant matrix; therefore, it is necessary to maintain a suitable time according to the target compound. If the dry sample has to be given high-pressure treatment, it will facilitate cell enlargement, leading to swelling and opening of pores in the cell membrane [82-85]. 


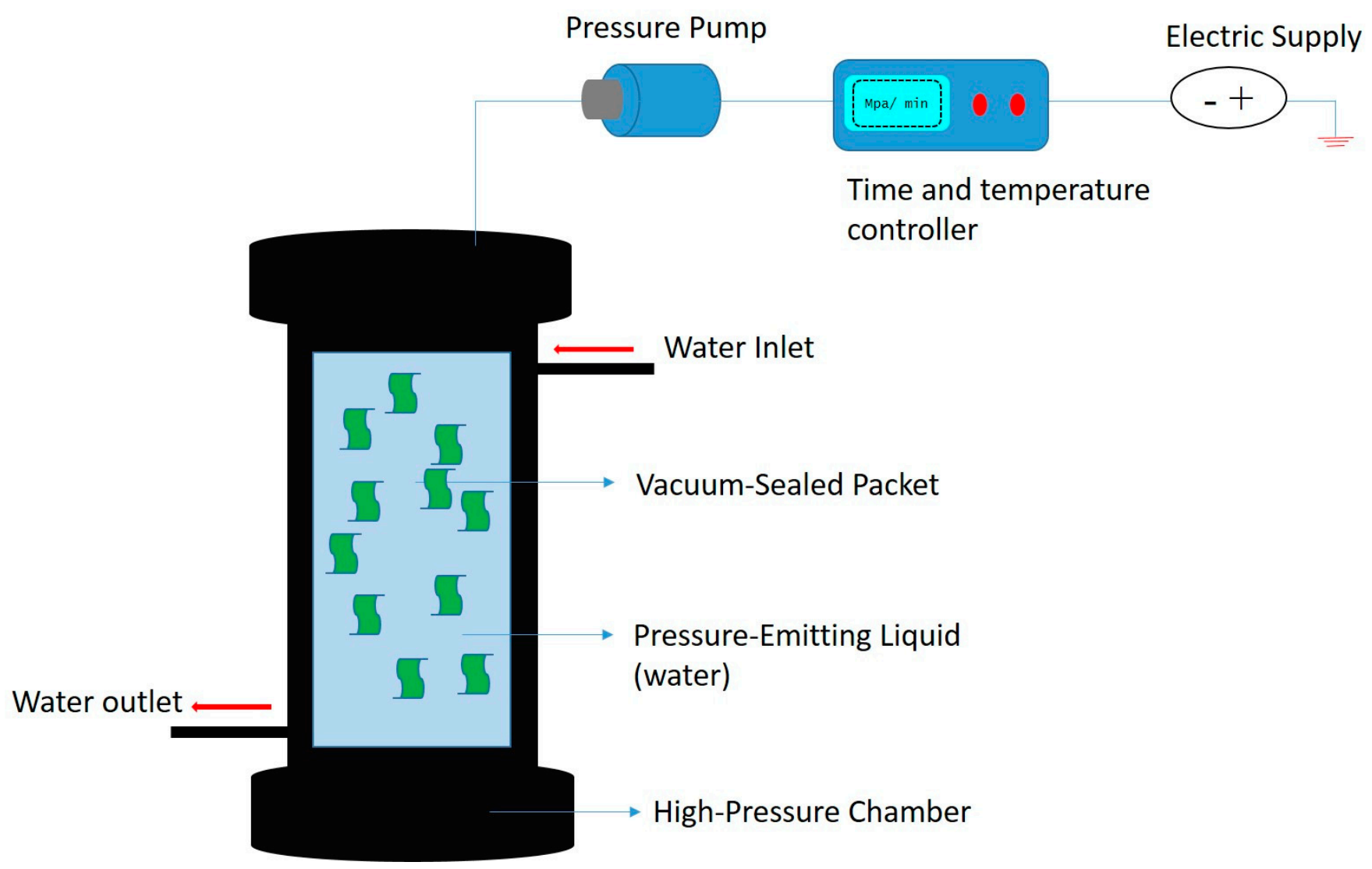

Figure 6. Schematic representation of high-pressure processing.

\subsection{Combination of Novel Stategies}

In the past few decades, researchers have been trying to enhance the extraction yield of bioactive compounds using novel technologies, but in order to further increase and purify the yield, combination strategies have been implemented, which mainly includes ultrasound-enzyme-assisted extraction, ultrasound-microwave-assisted extraction, microwave-enzyme-assisted extraction, ultrasound / microwave-enzyme-assisted extraction, pulse electric field enzyme-assisted extraction, supercritical fluid enzyme-assisted extraction and high-pressure enzyme-assisted extraction [86-89]. Each individual technique, such as ultrasound when applied on plant matrix, tends to enhance its mass transfer rate by rupturing the cell membrane; however, some portion of the cell membrane is still hindering the path, which can be removed by hydrolysis of the sample using enzyme treatment. Therefore, the combination treatment gained popularity and gave promising results. Table 1 illustrates extraction of bioactive compound saponin from several novel treatments individually, as well as in various combinations. 
Table 1. Novel extraction strategies for the extraction of bioactive compounds.

\begin{tabular}{|c|c|c|c|c|c|c|c|c|}
\hline Strategies & $\begin{array}{l}\text { Bioactive } \\
\text { Compounds }\end{array}$ & Matrix & Solvent & $\begin{array}{l}\text { Dilution } \\
\text { Ratio }\end{array}$ & $\begin{array}{l}\text { Extraction } \\
\text { Parameters }\end{array}$ & Time/Temp & Yield & Ref. \\
\hline \multicolumn{9}{|l|}{$\begin{array}{c}\text { Individual } \\
\text { Strategies }\end{array}$} \\
\hline \multirow{12}{*}{$\begin{array}{l}\text { Ultrasound- } \\
\text { assisted } \\
\text { Extraction }\end{array}$} & \multirow{7}{*}{ Saponins } & Zizyphus jujuba & Ethanol 50\% & $1: 36$ & $38 \mathrm{~W}$ & $50 \mathrm{~min}$ & $15.54 \%$ & [90] \\
\hline & & Quinoa & \multirow{4}{*}{ Ethanol } & \multirow{4}{*}{$1: 10$} & \multirow{4}{*}{$60 \% \mathrm{~A}$} & \multirow{4}{*}{$15 \mathrm{~min}$} & $5.51 \mathrm{~g} / 100 \mathrm{~g}$ & \multirow{4}{*}{ [91] } \\
\hline & & Lentil & & & & & $10.63 \mathrm{~g} / 100 \mathrm{~g}$ & \\
\hline & & Soyaben & & & & & $4.08 \mathrm{~g} / 100 \mathrm{~g}$ & \\
\hline & & Lupin & & & & & $4.55 \mathrm{~g} / 100 \mathrm{~g}$ & \\
\hline & & Alfalfa (Medicago sativa) & Ethanol $78.2 \%$ & $1: 11.4$ & $112.0 \mathrm{~W}$ & $2.84 \mathrm{~h} / 76.8^{\circ} \mathrm{C}$ & $1.61 \%$ & [92] \\
\hline & & Eclipta prostrasta L. & Ethanol 50\% & $1: 14$ & $100 \mathrm{~W}$ & $3 \mathrm{~h} / 70^{\circ} \mathrm{C}$ & $2.096 \%$ & [93] \\
\hline & $\begin{array}{l}\text { Total phenolic } \\
\text { compounds }\end{array}$ & $\begin{array}{l}\text { pomegranate (Punica } \\
\text { granatum L.) peel }\end{array}$ & Distilled water & $1: 4$ & $400 \mathrm{~W} / 60 \% \mathrm{~A}$ & $10 \mathrm{~min}$ & $69 \mathrm{mg} / \mathrm{g}$ & [94] \\
\hline & $\begin{array}{l}\text { Total phenolic } \\
\text { compounds }\end{array}$ & $\begin{array}{c}\text { Tamarillo fruit } \\
\text { (Solanum betaceum) }\end{array}$ & Acetone $80 \%$ & $1: 50$ & $50 \% \mathrm{~A}$ & $12 \mathrm{~min}$ & $23.96 \mathrm{mg} / \mathrm{g}$ & [95] \\
\hline & Flavonoids & $\begin{array}{l}\text { Lycium } \\
\text { barbarum L. fruits }\end{array}$ & $\begin{array}{l}\text { Mixture of choline } \\
\text { chloride and p-toluene } \\
\text { sulfonic acid }\end{array}$ & $1: 2 \mathrm{M}$ & $60 \% \mathrm{~A}$ & $1.5 \mathrm{~h}$ & $\begin{array}{l}\text { Myricetin (57.2 mg/g)Morin } \\
(12.7 \mathrm{mg} / \mathrm{g}) \text { Rutin }(9.1 \mathrm{mg} / \mathrm{g})\end{array}$ & [96] \\
\hline & $\begin{array}{c}\text { Flavonoids and } \\
\text { phenolic compounds }\end{array}$ & $\begin{array}{l}\text { Ocimum tenuiflorum } \\
\text { leaves }\end{array}$ & Ethanol 55. 34\% & $1: 40$ & $50 \mathrm{~W} / 0.26 \mathrm{~W} / \mathrm{cm}^{3}$ & $11.71 \mathrm{~min}$ & $\begin{array}{c}\text { Gallic acid } \\
(6.81 \mu \mathrm{g} / \mathrm{mL}) \\
\text { Vanillic acid }(8.52 \mu \mathrm{g} / \mathrm{mL}) \\
\text { Rutin }(14.21 \mu \mathrm{g} / \mathrm{mL}) \\
\text { Sinapic acid }(11.37 \mu \mathrm{g} / \mathrm{mL}) \\
\text { Quercetin }(3.49 \mu \mathrm{g} / \mathrm{mL}) \\
\text { Luteolin }(1.76 \mu \mathrm{g} / \mathrm{mL}) \\
\text { Apigenin }(8.66 \mu \mathrm{g} / \mathrm{mL})\end{array}$ & [97] \\
\hline & $\begin{array}{l}\text { Total flavonoids (TF) } \\
\text { and total phenolic } \\
\text { (TP) compounds }\end{array}$ & $\begin{array}{l}\text { wild garlic (Allium } \\
\text { ursinum L.) }\end{array}$ & Ethanol 50\% & $1: 5$ & $28.8 \mathrm{~W} / \mathrm{L}$ & $80 \mathrm{~min} / 80^{\circ} \mathrm{C}$ & $\begin{array}{l}\text { TP } 1.61 \mathrm{~g} \text { GAE/100 DW; } \\
\text { TF } 0.41 \mathrm{~g} \mathrm{CE} / 100 \mathrm{~g} \text { DW }\end{array}$ & [98] \\
\hline
\end{tabular}


Table 1. Cont

\begin{tabular}{|c|c|c|c|c|c|c|c|c|}
\hline Strategies & $\begin{array}{c}\text { Bioactive } \\
\text { Compounds }\end{array}$ & Matrix & Solvent & $\begin{array}{l}\text { Dilution } \\
\text { Ratio }\end{array}$ & $\begin{array}{l}\text { Extraction } \\
\text { Parameters }\end{array}$ & Time/Temp & Yield & Ref. \\
\hline & $\begin{array}{l}\text { Total phenolic } \\
\text { compounds }\end{array}$ & Peaches and Pumpkins & Ethanol 100\% & $1: 10$ & $44.60 \% \mathrm{~A}$ & $\begin{array}{c}27.86 \mathrm{~min} / \\
41.45^{\circ} \mathrm{C}\end{array}$ & Gallic acid $55 \mathrm{mg} / 100 \mathrm{~g}$ & [99] \\
\hline & Phenolic compounds & Sparganii rhizoma & Ethanol 80\% & $1: 22.74$ & $300 \mathrm{~W}$ & $33.54 \mathrm{~min}$ & $\begin{array}{c}\rho \text {-Hydroxybenzaldehyde }(2.12 \mu \mathrm{g} / \mathrm{g}) \\
\text { Vanillic acid }(21.66 \mu \mathrm{g} / \mathrm{g}) \\
\rho \text {-Coumaric acid }(4.32 \mu \mathrm{g} / \mathrm{g}) \\
\text { Ferulic acid }(2.08 \mu \mathrm{g} / \mathrm{g}) \\
\text { Rutin }(10.06 \mu \mathrm{g} / \mathrm{g}) \\
\text { Kaempferol }(106.35 \mu \mathrm{g} / \mathrm{g})\end{array}$ & [100] \\
\hline & Flavonoids & $\begin{array}{c}\text { Olive (Olea europaea) } \\
\text { Leaves }\end{array}$ & Distilled water & $1: 41$ & $270 \mathrm{~W}$ & $50^{\circ} \mathrm{C} / 50 \mathrm{~min}$ & $74.95 \mathrm{mg} \mathrm{RE} / \mathrm{g} \mathrm{dm}$ & [101] \\
\hline & Flavonoids & Grapefruit (Citrus paradisi L.) & Ethanol & $1: 8$ & $100 \mathrm{~W}$ & $25^{\circ} \mathrm{C} / 3 \mathrm{~min}$ & $75 \mathrm{mg}$ gallic acid equivalents/g dw & [102] \\
\hline \multirow{9}{*}{$\begin{array}{l}\text { Microwave- } \\
\text { assisted } \\
\text { Extraction }\end{array}$} & \multirow{9}{*}{ Saponins } & Furcraeaselloa var. marginata & Water & $\begin{array}{l}23.54 \\
\mathrm{~mL} / \mathrm{g}\end{array}$ & $2.45 \mathrm{GHz} / 1000 \mathrm{~W}$ & $9 \mathrm{~min} / 90^{\circ} \mathrm{C}$ & $5.77 \%$ & [103] \\
\hline & & $\begin{array}{l}\text { Physalis alkekengi L. var. } \\
\text { franchetii (Mast.) Makino }\end{array}$ & Ethanol $80 \%$ & $1: 32$ & $300 \mathrm{~W}$ & $29 \mathrm{~min}$ & $6.41 \mathrm{mg} / \mathrm{g}$ & [104] \\
\hline & & Phyllanthus amarus & Methanol 100\% & $1: 50$ & $\begin{array}{l}360 \mathrm{~W} / 4 \mathrm{~s} / \mathrm{Min} \\
\text { Irradiation time }\end{array}$ & $50 \mathrm{~min}$ & $227.9 \mathrm{mg} / \mathrm{g}$ & [106] \\
\hline & & Aralia elata (Miq.) & Ethanol 100\% & $1: 20$ & $560 \mathrm{~W} / 3$ cycles & $50 \mathrm{~min} / 40^{\circ} \mathrm{C}$ & $1.22 \mathrm{mg} / \mathrm{g}$ & [107] \\
\hline & & $\begin{array}{c}\text { Gac (Momordica } \\
\text { cochinchinensis Spreng.) } \\
\text { Seeds }\end{array}$ & Ethanol 100\% & $1: 30$ & $\begin{array}{l}360 \mathrm{~W} / \text { Irradiation } \\
\text { cycle } 10 \mathrm{~s} \text { on } 15 \mathrm{~s} \\
\text { off/cycle/3 cycles }\end{array}$ & $75 \mathrm{~S}$ & $26 \mathrm{mg} / 100 \mathrm{~g}$ & [108] \\
\hline & & Ganoderma atrum & Ethanol 95\% & $1: 25$ & $33 \mathrm{kHz}$ & $5 \mathrm{~min} / 90^{\circ} \mathrm{C}$ & $0.968 \%$ & [109] \\
\hline & & P. ginseng & Ethanol 45\% & $1: 20$ & $88 \mathrm{~W}$ & $180 \mathrm{~s} / 83.7^{\circ} \mathrm{C}$ & $1.31 \%$ & [110] \\
\hline & & Cacao pod husk & Methanol 85\% & $1: 50$ & $\begin{array}{l}600 \mathrm{~W} 6 \mathrm{~s} / \mathrm{min} \\
\text { irradiation time }\end{array}$ & $40 \mathrm{~min}$ & $69.9 \mathrm{mg}$ EE/g (Escin Equivalant) & [111] \\
\hline & & Paramignya trimera root & Methanol 100\% & $1: 100$ & $\begin{array}{l}360 \mathrm{~W} / 5 \mathrm{~s} / 2 \mathrm{~min} \\
\text { Irradiation time }\end{array}$ & $40 \mathrm{~min}$ & 520.5 mg escin equivalents (EE)/g & [112] \\
\hline
\end{tabular}


Table 1. Cont

\begin{tabular}{|c|c|c|c|c|c|c|c|c|}
\hline Strategies & $\begin{array}{l}\text { Bioactive } \\
\text { Compounds }\end{array}$ & Matrix & Solvent & $\begin{array}{c}\text { Dilution } \\
\text { Ratio }\end{array}$ & $\begin{array}{l}\text { Extraction } \\
\text { Parameters }\end{array}$ & Time/Temp & Yield & Ref. \\
\hline & Anthocyanin & Blueberry powder & Ethanol 55.5\% & $1: 34$ & 7 min Irradiation time & $47^{\circ} \mathrm{C}$ & $73.73 \%$ & {$[113]$} \\
\hline & Anthocyanins & $\begin{array}{c}\text { Purple corn } \\
\text { (Zea mays L.) cob }\end{array}$ & $\begin{array}{c}1.5 \mathrm{M} \mathrm{HCl}-95 \% \\
\text { Ethanol }\end{array}$ & $1: 20$ & $555 \mathrm{~W} / 19 \mathrm{~min}$ & $55^{\circ} \mathrm{C}$ & $185.1 \mathrm{mg} / 100 \mathrm{~g}$ & [114] \\
\hline & Rutin and Quercetin & $\begin{array}{l}\text { Stalks of Euonymus } \\
\text { alatus (Thunb.) Sieb }\end{array}$ & Ethanol 50\% & $1: 40$ & $170 \mathrm{~W} / 6 \mathrm{~min}$ & $\begin{array}{c}\text { Room } \\
\text { Temperature }\end{array}$ & $\begin{array}{c}\text { Rutin } 0.225 \mathrm{mg} / \mathrm{g} ; \\
\text { Quercetin } 0.012 \mathrm{mg} / \mathrm{g}\end{array}$ & [115] \\
\hline \multirow{5}{*}{$\begin{array}{l}\text { Enzyme- } \\
\text { assisted } \\
\text { Extraction }\end{array}$} & \multirow[b]{2}{*}{ Saponins } & $\begin{array}{c}\text { Gomphrena } \\
\text { celosioides Mart }\end{array}$ & Water & $1: 25$ & Cellulose $0.7 \%(v / w)$ & $4 \mathrm{~h} / 60^{\circ} \mathrm{C} / 5$ & $1.550 \%$ & [116] \\
\hline & & $\begin{array}{l}\text { Pseuderanthemum } \\
\text { palatiferum (Nees) } \\
\text { Radlk. Dry } \\
\text { Leaf Powder }\end{array}$ & Water & $1: 7.5$ & Viscozyme $7.5 \%$ & $75 \mathrm{~min} / 55^{\circ} \mathrm{C}$ & $2.267 \mathrm{mg} / \mathrm{g}$ & [117] \\
\hline & Flavonoids & Grape skins & Water & $1: 10$ & $\begin{array}{c}\text { Lallzyme EX-V } \\
(10.52 \mathrm{mg} / \mathrm{g}) \mathrm{pH} 2.0\end{array}$ & $3 \mathrm{~h} / 45^{\circ} \mathrm{C}$ & $0.012 \mathrm{mg} / \mathrm{g}$ & [118] \\
\hline & $\begin{array}{c}\text { Total flavonoids } \\
\text { and total } \\
\text { phenolic compounds }\end{array}$ & $\begin{array}{c}\text { Bay leaves } \\
\text { (Laurus nobilis L.) }\end{array}$ & Methanol 100\% & $1: 5$ & $\begin{array}{l}30 \text { mg of the ternary } \\
\text { enzyme mixture } \\
\text { (cellulase: hemicellulase: } \\
\text { xylanase; } 1: 1: 1\end{array}$ & $1 \mathrm{~h}$ at $40^{\circ} \mathrm{C}$ & $\begin{array}{c}\text { TPC } 5.87 \mathrm{mg} \mathrm{GAE} / \mathrm{g} ; \mathrm{TFC} \\
5.18 \mathrm{mg} \mathrm{QE} / \mathrm{g}\end{array}$ & [119] \\
\hline & Flavonoid compounds & Stevia rebaudiana & n-hexane & $6: 1$ & $\begin{array}{c}\text { pectinases and } \\
\beta \text {-glucanases }\end{array}$ & $100 \mathrm{~W} / 140^{\circ} \mathrm{C}$ & Luteolin $0.657 \mathrm{mg} / \mathrm{g}$ & [120] \\
\hline $\begin{array}{l}\text { Pulse electric } \\
\text { field-assisted } \\
\text { extraction }\end{array}$ & Saponins & Acanthophyllum Roots & Water & 1: 6 & $7 \mathrm{kV} / 60$ & - & $9.1 \%$ & [121] \\
\hline $\begin{array}{c}\text { High- } \\
\text { pressure } \\
\text { processing } \\
\text { extraction }\end{array}$ & Saponins & Bitter Melon & Ethanol 70\% & $1: 45.3$ & $423.1 \mathrm{MPa}$ & $7 \mathrm{~min} / 30^{\circ} \mathrm{C}$ & $\begin{array}{l}3.270 \mathrm{~g} \mathrm{Rg} 1 \text { equivalents } / 100 \mathrm{~g} \\
\text { (Ginsenoside standard) }\end{array}$ & [122] \\
\hline
\end{tabular}


Table 1. Cont

\begin{tabular}{|c|c|c|c|c|c|c|c|c|}
\hline Strategies & $\begin{array}{l}\text { Bioactive } \\
\text { Compounds }\end{array}$ & Matrix & Solvent & $\begin{array}{l}\text { Dilution } \\
\text { Ratio }\end{array}$ & $\begin{array}{l}\text { Extraction } \\
\text { Parameters }\end{array}$ & Time/Temp & Yield & Ref. \\
\hline \multicolumn{9}{|l|}{$\begin{array}{c}\text { Combine } \\
\text { Techniques }\end{array}$} \\
\hline $\begin{array}{l}\text { Ultrasound- } \\
\text { assisted } \\
\text { surfactant } \\
\text { Extraction }\end{array}$ & Saponins & Panax notoginseng & ethanol & $1: 6.25$ & $\begin{array}{c}1 \%(w / v) \text { of } \\
\text { DTAB/SDS vesicle }\end{array}$ & $20 \mathrm{~min}$ & & [123] \\
\hline $\begin{array}{c}\text { Pulse electric } \\
\text { field-assisted } \\
\text { enzyme } \\
\text { extraction }\end{array}$ & Saponins & Panax ginseng & $\begin{array}{c}\text { Water } / \beta- \\
\text { glucosidase } 2 \% \\
\left(4.7 \mathrm{pH} / 50^{\circ} \mathrm{C}\right)\end{array}$ & $1: 50$ & $15 \mathrm{kV} / 2 \mu \mathrm{s} / 10$ & & $38.15 \mathrm{mg} / \mathrm{g}$ & [125] \\
\hline $\begin{array}{l}\text { High- } \\
\text { pressure- } \\
\text { processing- } \\
\text { assisted } \\
\text { enzyme } \\
\text { extraction }\end{array}$ & Saponins & Ginseng Root & $\begin{array}{c}\text { Ethanol } \\
70 \% / \text { Cellulose } \\
60 \mu \mathrm{L} / 30 \mathrm{~mL}\end{array}$ & $1: 5$ & $100 \mathrm{MPa}$ & $12 \mathrm{~h} / 50^{\circ} \mathrm{C}$ & $40.02 \mathrm{mg} / \mathrm{g}$ & [126] \\
\hline \multicolumn{9}{|l|}{$\begin{array}{l}\text { Conventional } \\
\text { Extraction }\end{array}$} \\
\hline $\begin{array}{c}\text { Reflux } \\
\text { extraction }\end{array}$ & Sanonine & Bitter Melon & Ethanol 70\% & $1: 35$ & - & $3 \mathrm{~h}$ & $2.478 \mathrm{~g} / 100 \mathrm{~g}$ & [127] \\
\hline $\begin{array}{l}\text { Solvent } \\
\text { extraction }\end{array}$ & suporitits & $\begin{array}{c}\text { starfish } \\
\text { Echinaster sepositus }\end{array}$ & Methanol 70\% & $1: 50$ & Magnetic agitator & $\begin{array}{l}24 \mathrm{~h} / \text { Room } \\
\text { Temperature }\end{array}$ & $7.7 \mathrm{mg} / \mathrm{g}$ & [105] \\
\hline Maceration & Total Phenolics & $\begin{array}{l}\text { Blackberry (Rubus } \\
\text { fruticosus L.) residues }\end{array}$ & Ethanol 50\% & $1: 40$ & - & $80^{\circ} \mathrm{C}$ & $3.66 \mathrm{mg} \mathrm{GAE} / \mathrm{g}$ FR & [102] \\
\hline
\end{tabular}




\section{Nanoencapsulation of Bioactive Compounds}

Over the past few years, nanoencapsulation has gained popularity in the field of food science. It is a process of encapsulation whereby a bioactive compound as a core matrix is captured inside a wall matrix which can withstand the environmental and enzymatic degradation. Employing a significant wall matrix/nano-carrier provides protection against bioactive compounds, which are extremely sensitive to heat and digestive enzymes present in the stomach and gastrointestinal tract of the human body. Besides, these wall materials help in maintaining nutritional activity of the compound as well as helping in masking the undesirable taste of some of compounds [128]. Liposomes or lipid bilayer shells are considered best for encapsulation and delivery of bioactive compounds as they protect the compounds for a longer duration of time compared to other types of nano-carriers. In addition to this, casein micelles are considered promising to encapsulate minerals such as calcium and phosphate [129]. Nano-capsules generally range from 1 to $100 \mathrm{~nm}$ in particle size. Apart from the food industry, nanoencapsulation is also practiced by the packaging industry for packaging of meat and fruits to extend their shelf life with retained nutritional qualities [130].

Several nano-carriers including protein, casein, chitosan, gelatin, zein, polyethylene glycol, arabinogalactan, poly-D, L-lactide-co glycolide, poly L-lysine and polyaniline are used for encapsulation. According to literature, chitosan-based glycolipid nano-carriers have the tendency to enhance the anticancer activity of fucoxanthin by 25.8 -fold, as they help to keep the compound active for a longer period of time [131]. In different studies, rutin was encapsulated using poly (lactic-co-glycolic acid) and zein as a wall matrix, which resulted in a slow delivery rate $(25 \%$ after $60 \mathrm{~h})$ of rutin at the targeted location in the human body [132]. Presently, one of the researchers used chitosan and alginate to encapsulate bioactive compounds from the waste of grapes, in which, interestingly, the bioactivity of the targeted compound was enhanced and the encapsulation protected the compound from degradation in the gastrointestinal tract [133]. Besides, compounds including peptides are encapsulated using lipid-based nano-carriers or liposomes, which are comprised of double-layer protection of surfactant molecules and aqueous fluid [134]. Furthermore, nano-carriers of hybrid structure (combination of liposome and chitosan) are also in practice to encapsulate compounds like caffeine to enhance the encapsulation efficiency [135].

The techniques employed to encapsulate these compounds are divided into categories based on power consumed for encapsulating, such as top-down and bottom-down techniques as well as their combined treatment [136]. In the case of the top-down method of encapsulation, high power consumption takes place as it is equipped with instruments like spray-drying, ultra-sonication, homogenizer and many more, while the bottom-down method is practiced in minimum consumption of energy; for example, precipitation, micro-emulsification, conjugation, interchange of atoms, etc. Major factors which play a vital role in selecting a particular technique for nanoencapsulation are delivery motive, delivery rate of release, solubility and stability of the nano-carrier, as well as cost of production [131].

\subsection{Encapsulating Carriers for Bioactive Compounds}

\subsubsection{Polymeric Nano-Carriers}

Polymeric nano-carriers are considered to be extremely suitable material for encapsulation and delivery of bioactive compounds. Presently, natural-based nano-carriers including casein, starch, chitosan, whey protein and albumin are maximum used. In 2018, Ravi et al. [132] used chitosan as a wall material to encapsulate marine carotenoid fucoxanthin. It resulted in enhanced anticancer activity of the bioactive compound and increased the caspase-3 activity 25.8-fold. Further, Gagliardi et al. [133] carried out a comparative study using synthetic and natural-based nanoparticles, namely, poly (lactic-co-glycolic acid) and zein for the encapsulation of rutin. The results indicated that zein loaded with $0.8 \%$ rutin concentration reflected slower release $(25 \%)$ after $60 \mathrm{~h}$ as compared to poly 
(lactic-co-glycolic acid) (100\%). Further, in 2021, Portugal researcher Costa et al. [134] encapsulated bioactive grape pomace extract using chitosan and alginate nanoparticles, which protected the bioactive compounds from hydrolysis in the gastrointestinal tract as well as enhanced its bioactivity.

\subsubsection{Lipid-Based Nano-Carriers}

Lipid-based nano-carriers, known as vesicular carriers, include nano-liposomes, niosomes and particulate carriers (solid lipid nanoparticles and nano-structured lipid carriers). It is a spherical bilayer developed by the reaction between surfactant molecule and aqueous fluid. It is used to encapsulate various bioactive compounds including peptide. Solid lipid nanoparticles are fabricated by mixing solid lipid in internal phase, whereas nano-lipid particles are developed by mixing liquid and solid lipid together [137]. Chaudhari et al. [138] encapsulated piperine and quercetin using Compritol as a solid lipid, while squalene as liquid lipid and span 80 as well as tween 80 as emulsifiers and co-emulsifier. These encapsulated bioactive compounds reflected slower release due to slower erosion of lipid wall matrix (12 h). Another study conducted by Abd-Elhakeem et al. [139] illustrated about improving the bioavailability and oral target delivery of eplerenone by using lipid-based nanoencapsulation. Eplerenone-loaded nano-lipid capsules reflected in improved permeability up to two folds higher compared to conventional aqueous drug in rabbit intestine after the period of $24 \mathrm{~h}$.

\subsubsection{Hybrid Nano-Carriers}

Hybrid nano-carriers consist of two main networks including internal (metallic materials and polymers) and external (single/multi-lipid layer) networks. The outer layer of this nano-particle acts as a protection against deterioration and water diffusion. These organic-inorganic and lipid-polymer carriers are basically developed for the treatment of cancer cells with controlled release of bioactive compounds. Seyedabadi et al. [136] developed a slow-release encapsulated caffeine using chitosan coated in nano-liposomes as compared to nano-liposome without chitosan covering; hence, combination of chitosome proved better for the encapsulation of caffeine.

\subsection{Nanoencapsulation Techniques for Encapsulation of Bioactive Compounds}

Nanoencapsulation of bioactive compounds is significantly more complex as compared to the micro-encapsulation process. It is divided into three main categories, which consist of top-down, bottom-down and a blend of both [131]. Top-down techniques require high-energy-efficiency instruments including spray-drying, ultra-sonication, high-pressure homogenization, etc., while the bottom-down technique is limited to low-energy-consumption techniques, such as precipitation, micro-emulsification, conjugation, layer-wise accumulation, interchange of atoms and molecular into nano-size level, etc. [137]. Several factors influence the choice of a particular technique for tailoring nano-capsules, which include delivery motive, delivery rate of release, solubility and stability of the nano-carrier, as well as cost of production.

In the present review, several encapsulation techniques including ultra-sonication, high-pressure homogenization, microfluidization, nano-fluidics, nano-spray-drying, electrospinning, electro-spraying, milling and vortex fluidic have been discussed.

\subsubsection{Electrospinning}

In electrospinning, fluids with electric charges are processed by passing highvoltage electricity to polymeric fluid, which results in the development of dry microand nano-structures. Basically, the instrument comprises three major parts including a syringe pump, stainless steel electrified needle, and the collector plate inside a chamber. The feed fluid is pushed with a definite flow-rate inside the nozzle/needle, which is subjected to high-voltage electricity. The experiments are carried out at ambient 
temperature and after the nano-fibers are collected on the electric collector plate, they are kept in a desiccator prior to packaging [140]. The principal element responsible for the characteristic of nano-fiber includes operating conditions such as spinning fluid properties, polymer attributes and mechanical parameters of the instrument with its several nozzle setups [141]. The diameter of nano-fibers ranges from $1 \mu \mathrm{m}$ to numerous nano-meters. These nano-fibers are in demand as a reinforced material in food packaging, drug delivery, and biosensing due to its substantial surface area, flexibility to develop into several structures and magnified porosity [142]. There are five different types of electrospinning strategies including blend electrospinning, coaxial electrospinning, emulsion electrospinning, high-throughput electrospinning and polymer-free electrospinning. In the blend and emulsion electrospinning method, the core (bioactive compound) and the wall (polymeric) solutions are blended together for electrospinning using single-nozzle, which works efficiently in controlling the release of bioactive compounds. Hydrophilic and hydrophobic molecules can be easily encapsulated using this technique [143]. On the contrary, in the case of a coaxial electrospinning setup, the component consists of a syringe with a twin-compartment, where two different nozzles are attached to one syringe outlet pump for electrospinning the core and wall solution together, which results in achieving encapsulated fibers [144]. However, highthroughput electrospinning is a needless technique applicable for the fabrication of ultrathin fibers via emulsions subjected to centrifugal pressure of polymeric fluid. In 2018, Kutzli produced glycoconjugates using high-throughput electrospinning. Apart from all these techniques, polymer-free electrospinning is an enhanced version of electrospinning, wherein the polymeric fluid with high molar mass is injected through a pump on the surface to achieve higher yield than the conventional techniques [145]. Xiao et al. [146] indicated that this technique was able to fabricate nano-fibers of a diameter ranging from 87 to $57 \mathrm{~nm}$, whereas other reports by Moreira et al. [147] indicated that polymer-free electrospinning is useful for the food industry to improve the uniformity of nano-fibers derived from spirulina. Further, Poornima et al. [148] used electrospinning to encapsulate resveratrol with poly( $\varepsilon$-caprolactone) and poly (lactic) acid and the results proved to be effective in controlled drug release delivery, while another recent study by Leena and Anandharamakrishnan et al. [149] achieved the highest encapsulation efficiency (96.9\%) of resveratrol using Zein. Researchers also indicated that these nano-fibers are useful as edible nano-films for oral delivery.

\subsubsection{Electrospraying}

Elcetrospraying, popularly known as electro-hydro-dynamic atomization (EHDA), is an alternate solution for the drying-encapsulation technique. It runs on high-voltage electric current at ambient temperature. The primarily principle for both the techniques (electrospinning and the electrospraying) is similar, the unique difference between these technologies lies in intermolecular cohesion of polymeric fluid which is remarkably low in the case of electrospraying, and thus results in breakage of jet into fine droplets. The jet particles, when exposed in air, gain a spherical shape in view of the surface tension. A report by Bhushani and Anandharamakrishnan [140] revealed that electrospraying helps to enhance the permeability and bioactive releasing attributes in catechins from green tea with the help of zein as a wall material. Later in 2019, Jayan and Anandharamakrishnan also revealed that resveratrol, when nanoencapsulated using the same wall material, results in $68 \%$ encapsulation efficiency [150].

\subsubsection{Nano-Spray Dryer}

The nano-spray-drying technique is quite similar to that of conventional spray-drying, where the fluid is subjected to droplet formation and further dried by the heated drying gas to form dry particles. In the case of nano-spray, the little modification has been made which includes a particular nozzle, which fabricates nano-droplets using a constant flow of drying gas used from laminar. Further, the nano-droplets are subjected to vibrating mesh of 4.0, 
5.5 , and $7.0 \mu \mathrm{m}$ size holes. The fragment size of the spray-dried sample totally depends on the concentration of the fluid, temperature of drying gas, spray velocity and the size of the droplets [151]. Adel et al. [152] encapsulated curcumin in hydroxypropyl beta-cyclodextrin using the nano-spray-drying technique for the pulmonary delivery of curcumin in lung tissues and the results indicated significant reduction of proinflammatory cytokines compared to the pure drug. Further, Mozaffar et al. [153] dried nano-structured lipid carriers of 3\% palm oil and $3 \%$ tween $80(60 \mathrm{~g} / \mathrm{L})$ mixed with sodium chloride. The results revealed that the presence of sodium chloride protected nano-structured lipid carriers from aggregation during the process of spray-drying and about $50 \%$ of lipid molecules were encapsulated in salt particles.

\subsubsection{Micro-/Nano-Fluidics}

The primary concept of micro-/nano-fluidics is based on interfacial interaction between the core and wall fluids. It helps in the formation of spherical drops and slows down the release of the bioactive compounds. In addition to this, it helps in the production of similar-size accurate nano-droplets [154]. It consists of components including a molded set of channels fabricated on a base of polydimethylsiloxane (PDMS) of glass. The fluid is passed through this channel as these are interconnects from all directions. Gas and liquid are injected from a syringe using hydrostatic pressure. Generally, this technique incorporated four types of emulsion devices including single-, double-, multi- and flow-focusing nano-/microfluidic devices. It is employed for the fabrication of nano-emulsions, nano-liposomes and nanoencapsules. Jafari et al. [155] developed an oil-in-water nano-emulsion using microfludization at an optimized condition of 42-63 MPa microfluidization pressures with 1-2 cycles. The results of the study indicated smaller droplets of fish oil in developed nano-emulsion. After a couple of years, Wang et al. [156] modified citrus pectin using microfluidation, and the results revealed that properties of nano-emulsion were enhanced, thereby protecting cholecalciferol from UV degradation as compared to the original pectin. In addition, the molecular weight and hydrodynamic diameter of modified pectin was also reduced to $237.69 \mathrm{kDa}$ and $418 \mathrm{~nm}$, respectively.

\subsubsection{High-Pressure Homogenization}

High-pressure homogenization refers to the production of nano-fragments of a homogenous size in a fluid under a specific high pressure. It comprises 10-15-fold higher pressure (100-400 MPa) than conventional homogenizer. According to the research, this technique is excessively utilized by the milk and milk products industries to upgrade its texture, taste, flavor, and improved shelf life characteristics with enhanced anti-microbial quality (in activation of Salmonella spp., Listeria monocytogenes, Staphylococcus aureus, and Escherichia coli). About 3 and $4 \log$ cycles reduction was reported at 200 and $300 \mathrm{MPa}$ homogenization pressure at $30{ }^{\circ} \mathrm{C}$ and $40{ }^{\circ} \mathrm{C}$ inlet temperature [157]. It also acts as a substitute against thermal processing, as it is significantly effective for the inactivation of enzymes and microbial activity [158]. Additionally, it also helps in the development of nano-emulsion, which is stable at ambient condition. Fernandez-Avila et al. [159] developed a soy protein isolate-stabilized emulsion employing high-pressure homogenization, and the results revealed that emulsion treated with 100 to $200 \mathrm{MPa}$ with $20 \%$ soybean oil was most stable with its improved physical stability in terms of particle size and rheology.

\subsubsection{Ultrasonication}

"Ultrasound" is a cluster of sound waves beyond human hearing frequency $(>16 \mathrm{kHz})$. Basically, it is divided into two streams, low- and high-intensity waved; low sound waves are generally used for the detection purpose (sonography), whereas high sound waves are used for the modification in molecules including its size reduction, it also helps in the development of emulsification and extensively utilized by the food industries [160]. In nano- 
technology, it is basically utilized for the development of several genres of nano-structure. The components of ultrasound comprise an electric generator, piezoelectric transducer for transforming electrical energy into sound energy and a sound emitter of titanium horn shape for conveying the ultrasonic waves into the sample or medium [161]. Various ranges of nano-delivery techniques have been developed, incorporating lipid and surfactant molecules as a wall material for the fabrication of nano-emulsions, nano-liposomes, niosomes, etc., using ultrasound [162-164]. Nano-carriers such as biopolymeric and polymeric have also been developed for the encapsulation of various food bioactive compounds by the food industry.

\subsubsection{Supercritical-Based Technologies}

It is an alternate green method for the development of nano-particles [165]. Principally, the temperature of critical solvent is above its critical limit or at single phase irrespective of pressure. Carbon dioxide is commonly used as a supercritical fluid as it is nontoxic, low cost and non-flammable. In this process, a liquid solvent is employed, which could absolutely mix with the super critical fluid such as carbon dioxide so as to liquefy the solute subjected to micro-ionization. Now, due to the insolubility of solute in the super critical fluid, instant precipitation takes place, which further brings out the outcome of developed nano-particles [166]. Presently, methods including micronization via rapid expansion of supercritical (RESS) solution, supercritical antisolvent (SAS), supercritical melt micronization (ScMM), spray coation, supercritical $\mathrm{CO}_{2}$ coating, etc. are employed for encapsulation of bioactive compounds using supercritical system. Several researchers indicate that this technology can be useful in various ways including development of encapsulated products depending upon properties of wall matric and the active ingredients. Based on the behavior of the core and wall material to be encapsulated, the processing technique using supercritical $\mathrm{CO}_{2}$ is decided. For example, the interaction of $\mathrm{CO}_{2}$ with the active material, wall material and the solvent used. In case of a biopolymer drug delivery system, the interface between the supercritical $\mathrm{CO}_{2}$ and the polymer used plays a vital role in encapsulation process. Whereas polymer including polylactide (PLA) is good for SAS treatment, in the case of RESS, it is difficult to solubilize in supercritical $\mathrm{CO}_{2}[167,168]$.

\subsubsection{Polymerization}

In this technique of nano- encapsulation, firstly, to form nano-particles, monomers of an aqueous fluid are polymerized then the bioactive compound is mixed in it. Further, when the encapsulation takes place, the nano-particles are purified by removing extra stabilizer and surfactant settled on the surface of the nano-particles. This technique is generally incorporated for developing poly butylcyanoacrylate nano-particles $[169,170]$.

\subsubsection{Coacervation or Ionic Gelation}

A technique with wide range of hydrophilic compounds (gelatin, sodium alginate and chitosan) was incorporated for the development of nano-particles. Two kinds of aqueous phase fluids are prepared using chitosan polymer (propylene oxide) and polyanion sodium tripolyphosphate. A nano-size coacervation is formed when the tripolyphosphate (negative charged) reacts with chitosan (positively charged) and, due to the reaction of ions, liquid is converted into gel [171].

\section{Physicochemical Properties of Encapsulated Bioactive Compounds}

\subsection{Particle Size}

The foremost properties of nano-particles are the size of its particle and its distribution. These properties are responsible for overall quality including its delivery ability, stability, viscosity, etc. [172]. Due to the relative mobility and significantly tiny size, the intracellular holding capacity is relatively higher in nano-particles than micro-particles. Reports reveal 
that nano-particles of $100 \mathrm{~nm}$ reflected 2.5 times higher holding capacity compared to $1 \mu \mathrm{m}$ micro particles [173].

Several types of microscopes are used to detect the size and structure of the nanoparticles. Optical properties of nano-particles including single/double/multi-emulsions and micro/nano-capsules capsule are measured by scanning electron microscope/laser diffraction based on its properties (wet/dry). To determine the number of pores, surface study is required which needs extremely strong analyzers such as transmission electron microscopy. Several compound locations can be detected using confocal or fluorescence microscopy by mixing fluorophores to dye the bioactive compound. Dynamin light scattering, also known as photon correlation spectroscopy, is extensively utilized to detect size of the nano-particles, which are in the range of $1000 \mathrm{~nm}$. It helps in finding the range of particle size along with its concentration in the given matrix [174]. It is operated to identify the charge attributes of the nano-particles. It indicates the electrical capacity of the nano-particles, which can further be modified by changing the composition of compounds mixed in the aqueous fluid. Zeta potential more than $(+/-) 30 \mathrm{mV}$ of a nano-particle is known to be stable. Interestingly, with the help of the Zeta potential test, it can be identified whether the wall material has been encapsulated inside the nano-capsule or covering its outside structure [175]. Desai et al. [176] reported that nano-particles can diffuse through the submucosal layers in rats while a micro-particle is only limited till the epithelial lining.

\subsection{Stability of Encapsulated Bioactive Compound}

"Stability of nano-particles" refers to the strength and balance needed by nanoparticles to remain intact inside the wall matrix until the desired time and place of release. Nano-emulsions have better stability due to their morphological structure of tiny droplets. Additionally, the strength of bioactive compound to remain stable can be examined by placing them in a modified environment including high/low temperature, different ionic charge fluids and different $\mathrm{pH}$ range [177].

\subsection{Encapsulation Efficiency and Loading Capacity}

It is defined as the amount of bioactive compound encapsulated inside the wall matrix. The amount of compound encapsulated can be quantified by using techniques including high-performance liquid chromatography, UV-Vis spectroscopy and UV-Vis spectroscopy [178]. A perfect nano-particle is the one which has maximum compound loading capacity with minimum quantity of wall material. Loading of bioactive compounds can be carried out using two methods including incorporation and absorption methods. The capacity of entrapment is basically dependent on solubility of the compound encapsulated in the wall material, specifically the interaction in the molecules of bioactive compound-polymer, molecular weight and the availability of functional groups [179]. Proteins and macromolecules at isoelectric degree are reported to possess maximum holding capacity. Moreover, in the case of smaller molecules, the ionic reactions between compound and polymer can help in increasing the holding capacity of the matrix.

\subsection{Control Release}

The release of the bioactive compounds encapsulated in a particular matrix depends on several aspects including compound solubility, surface bound/adsorption, and diffusion from the matrix, matrix degradation and combination of both diffusion and degradation. Nano-spheres with even distribution of bioactive compounds tend to release by erosion of wall material. The process of release is totally controlled by diffusion if degradation of wall material takes place at a slow rate. The quick release of the compound results in poor wall material or low bounding capacity of the compound [180]. It was reported that the mixing method practiced plays a vital role on release profile of nano-capsules as it will slow the release of compounds [181]. In contrast 
to this, if the compound is protected by the polymer coating, then the release takes place by the diffusion method from inside to matrix outside. Further, there are several techniques including ultra-filtration, reverse dialysis bag, dialysis bag and diffusion of cell with synthetic of artificial membrane that is practiced for the compound release in vitro.

\section{Application of Nanoencapsulation in Food Industries}

Application of nanoencapsulation in several industries including nutraceutical, pharmaceutical, food, packaging and preservation has exponentially expanded in the last few years. It is extremely promising for the fragrance and flavor industries as the volatile compounds tend to evaporate during processing time. Besides, these compounds undergo chemical changes due to oxidation at atmospheric condition, which results in degradation of the compounds, thus encapsulation helps to stabilize as well as retain the natural color, flavor and fragrance while enhancing the shelf life of the compound. An excellent example is retaining the fresh aroma of brewed coffee through microencapsulation of flavor compounds such as ketones, pyrazines, furans, pyridines, etc., using food starch derived from waxy maize as encapsulating material. Nanoencapsulation of tea compounds (caffeine, theanine and catechins) using various proteins, lipids and carbohydrates have been reported to increase the effectiveness of their health imparting properties such as anticancer, antidiabetic and anti-inflammatory [182-184].

It has been researched and reported that during gastrointestinal digestion, encapsulated catechin showed improved retention of its biological properties as compared to free catechin [185]. Rojas-Graü et al. [186] revealed that the nanoencapsulation technique can be utilized as an anti-browning technique for food industries. Nanoencapsulated plant-based compounds are tagged as anti-browning compounds. Tyrosinase enzyme, also known as catalase $B$, accelerates the unwanted chemical reaction during food processing including enzymatic browning of fruits, vegetables and beverages that causes adverse effects on its organoleptic characteristics (Polyphenol Oxidase $+\mathrm{O}_{2} \rightarrow$ Melanin). Zheng et al. [187] isolated tyrosinase inhibitors from Artocarpus heterophyllus to retard browning reacting in fresh-cut-apple slices. The results revealed that apple slices treated with Artocarpus heterophyllus extract along with $0.5 \%$ ascorbic acid reflected no browning reaction after $24 \mathrm{~h}$.

Further, nanoencapsulation is popularly appreciated for improving the water stability, solubility and bio-accessibility of hydrophobic bioactive compounds including curcumin by binding it with naturally existing proteins (legume oligomeric globulins, ferritin and casein micelles) by a hydrophobic interactions bond which acts as a nanocarrier for hydrophobic nutraceuticals in drug delivery [188]. Human Serum Albumincurcumin nano-particles can be used for cancer treatment as they reflect effective antioxidant activity with enhanced antitumor properties [189]. Luo and co-workers [190] carried out ex vivo and in vivo adhesion experiments employing Tannic acid/IR780nano-particles, which were tailored with anti-ulcerative colitis properties (encapsulated Curcumin). Reports reveal that tannic acid-loaded curcumin nano-particles can be utilized for drug delivery to treat ulcerative colitis as tannic acid possesses degradable adhesive properties which can accumulate on the surface of inflamed mucosa. In Figure 4, ulcerative colitis mice were orally ingested with three different solutions including free IR780, IR780 nano-particles and tannic acid/IR780- nano-particles. A gradual decrease in adherence level was noticed in all the three samples at different time intervals $(3 \mathrm{~h}, 6 \mathrm{~h}, 12 \mathrm{~h}$, and $24 \mathrm{~h}$ ). Mice with tannic acid/IR780-nano-particles reflected the maximum adherence towards inflamed mucosa. Additionally, nanoencapsulation is also considered as an effective technique for encapsulating antidiabetic synthetic compound insulin. In 2021, Hadiya et al. [191] encapsulated insulin using chitosan to $170-800 \mathrm{~nm}$ size of spherical shape and about $15-52 \%$ of delivery efficiency was achieved. 
Nanoencapsulation is also useful in active packaging, which helps to prolong shelf life and preserve quality of the food products. It is employed to retain and enhance the nutritional and organoleptic attributes of the product with extended shelf life [192]. Encapsulated bioactive compounds rich in antioxidants and antimicrobials including vitamin C, Vitamin E, carotenoids, etc., are incorporated to edible films as active compounds during the fabrication as it helps in maintaining the level of freshness of the products. The organoleptic attributes of the coated product can be maintained by incorporating additional flavor, colors and sweeteners. Nano-fibers of cinnamon EO encapsulated in polyvinyl alcohol $/ \beta$-cyclodextrin are obtained to use as a film for coating the packaging box. The film coating (1.5 cinnamon EO- $\beta$-cyclodextrin) acts as an antimicrobial barrier to suppress bacterial and fungal spoilage of the food sample while extending its shelf life by $5 \mathrm{~d}$ at $10 \pm 0.5^{\circ} \mathrm{C}$ [193]. Adel et al. [194] prepared a bio-composite using $\beta$-cyclodextrin citrate $(50 \%)$, and oxidized nano-cellulose $(7 \%)$ in chitosan solution. The prepared film reflected in reduced water vapor permeability $2.09 \pm 0.08$ (10-11 $\left.\mathrm{g} \mathrm{m}^{-1} \mathrm{~s}^{-1} \mathrm{~Pa}^{-1}\right)$. In addition, the film was fortified with clove EO nano-particles, which resulted in higher activity of Gram-negative bacteria than Gram-positive. Further, Xiao et al. [195] developed a nano-composite film by encapsulating pesticide/insecticide (iprodione) using poly (ethylene glycol)-poly ( $\varepsilon$-caprolactone and chitosan. The encapsulation of iprodione reflected in its improved efficacy by 2 -fold along with its reduced dosage.

\section{Conclusions and Prospects}

At present, due to the tremendous growth of deadly diseases, it has become necessary for humankind to build up a strong immune system and this could be only possible though ingestion of bioactive compounds extracted from plant sources. This scenario has encouraged researchers to search for the conventional and sustainable extraction method for collection of bioactive compounds from plant matrixes. Nevertheless, application of these novel extraction techniques still remains a challenge due to its working principal as it works on several parameters; therefore, in-depth knowledge is required to follow this technique on the larger scale at the industrial level to achieve a promising output. However, due to the evolution of these novel techniques, the extraction has become easy and the extraction yield has been significantly enhanced in maximum bioactive compounds. Novel technologies have helped in enhancing the extraction of bioactive compounds without significant degradation. Moreover, encapsulation techniques offered to deliver the bioactive compounds at the site where it is needed. The combination of these two techniques offers a synergistic effect for extraction as well as targeted delivery.

Author Contributions: S.N., writing—original draft preparation; N.K.R., writing—review and editing; C.O., writing — review and editing; and B.T., writing—review and editing. All authors have read and agreed to the published version of the manuscript.

Funding: The authors and their work were supported by the Irish Department of Agriculture, Food and the Marine, under the Food Institutional Research Measure to the U-Protein project under grant No. 2019PROG702.

Conflicts of Interest: The authors declare no conflict of interest.

Entry Link on the Encyclopaedia Platform: https:/ / encyclopedia.pub/13442 the entry published on the encyclopedia platform.

\section{References}

1. Talmaciu, A.I.; Ravber, M.; Volf, I.; Knez, Z.; Popa, V.I. Isolation of bioactive compounds from spruce bark waste using sub- and supercritical fluids. J. Supercrit. Fluids 2016, 117, 243-251. [CrossRef]

2. Perinelli, D.R.; Palmieri, G.F.; Cespi, M.; Bonacucina, G. Encapsulation of flavours and fragrances into polymeric capsules and cyclodextrins inclusion complexes: An update. Molecules 2020, 25, 5878. [CrossRef] 
3. Barbosa, R.F.S.; de Souza, A.G.; Rangari, V.; dos Santos Rosa, D. The influence of PBAT content in the nano-capsules preparation and its effect in essential oils release. Food Chem. 2021, 344, 128611. [CrossRef]

4. Gupta, S.; Khan, S.; Muzafar, M.; Kushwaha, M.; Yadav, A.K.; Gupta, A.P. 6-Encapsulation: Entrapping essential oil/flavors/aromas in food. Encapsulations 2016, 2, 229-268. [CrossRef]

5. Coelho, S.C.; Estevinho, B.N.; Rocha, F. Encapsulation in food industry with emerging electrohydrodynamic techniques: Electrospinning and Electrospraying-A review. Food Chem. 2020, 339, 127850. [CrossRef]

6. Vinatoru, M. An overview of the ultrasonically assisted extraction of bioactiveprinciples from herbs. Ultrason. Sonochem. 2001, 8, 303-313. [CrossRef]

7. Paulsen, B.S. Highlights through the history of plant medicine. In Proceedings of the Symposium Held at the Norwegian Academy of Science and Letters, Oslo, Norway, 13-14 November 2010. Available online: C:/Users/shaba.noore/Downloads/31 110_Bioactive_compounds_in_plants\%20(1).pdf (accessed on 11 June 2021).

8. Croteau, R.; Kutchan, T.M.; Lewis, N.G. Natural products (secondary metabolites). In Biochemistry and Molecular Biology of Plants; Buchanan, B., Gruissem, W., Jones, R., Eds.; American Society of Plant Physiologists: Rockville, MD, USA, 2000; pp. 1250-1318.

9. Wink, M. Evolution of secondary metabolites from an ecological and molecular phylogenetic perspective. Phytochemistry 2003, 64, 3-19. [CrossRef]

10. Chemat, F.; Rombaut, N.; Sicaire, A.-G.; Meullemiestre, A.; Fabiano-Tixier, A.-S.; Abert-Vian, M. Ultrasound assisted extraction of food and natural products. Mechanisms, techniques, combinations, protocols and applications. A review. Ultrason. Sonochem. 2017, 34, 540-560. [CrossRef]

11. Kovačević, D.B.; Maras, M.; Barba, F.J.; Granato, D.; Roohinejad, S.; Mallikarjunan, K.; Montesano, D.; Lorenzo, J.M.; Putnik, P. Innovative technologies for the recovery of phytochemicals from stevia rebaudiana bertoni leaves: A review. Food Chem. 2018, 268, 513-521. [CrossRef]

12. Azmir, J.; Zaidul, I.S.M.; Rahman, M.M.; Sharif, K.M.; Mohamed, A.; Sahena, F.; Jahurul, M.H.A.; Ghafoor, K.; Norulaini, N.A.N.; Omar, A.K.M. Techniques for extraction of bioactive compounds from plant materials: A review. J. Food Enginr. 2013, 117, 426-436. [CrossRef]

13. Chemat, F.; Huma, Z.-e.; Khan, M.K. Applications of ultrasound in food technology: Processing, preservation and extraction. Ultrason. Sonochem. 2011, 18, 813-835. [CrossRef]

14. Tiwari, B.K. Ultrasound: A clean, green extraction technology. TrAC Trends Anal. Chem. 2015, 71, 100-109. [CrossRef]

15. Rostagno, M.A.; Prado, J.M. Natural Product Extraction: Principles and Applications; The Royal Society of Chemistry's: London, UK, 2013.

16. Alexandru, L.; Cravotto, G.; Giordana, L.; Binello, A.; Chemat, F. Ultrasound-assisted extraction of clove buds using batch-and flow-reactors: A comparative study on a pilot scale. Innov. Food Sci. Emerg. Technol. 2013, 20, 167-172. [CrossRef]

17. Wen, C.; Zhang, J.; Zhang, H.; Dzah, C.; Zandile, M.; Duan, Y.; Ma, H.; Luo, X. Advances in ultrasound assisted extraction of bioactive compounds from cash crops-A review. Ultrason. Sonochem. 2018, 48, 538-549. [CrossRef] [PubMed]

18. Capelo-Martínez, J. (Ed.) Ultrasound in Chemistry: Analytical Applications; John Wiley \& Sons: Hoboken, NJ, USA, 2009.

19. Marić, M.; Grassino, A.N.; Zhu, Z.; Barba, F.J.; Brnčić, M.; Brnčić, S.R. An overview of the traditional and innovative approaches for pectin extraction from plant food wastes and by-products: Ultrasound-, microwaves-, and enzyme-assisted extraction. Trends Food Sci. Technol. 2018, 76, 28-37. [CrossRef]

20. Shirsath, S.; Sonawane, S.; Gogate, P. Intensification of extraction of natural products using ultrasonic irradiations-A review of current status. Chem. Eng. Process. Process. Intensif. 2012, 53, 10-23. [CrossRef]

21. Rastogi, N.K. Opportunities and challenges in application of ultrasound in food processing. Crit. Rev. Food Sci. Nutr. 2012, 51, 705-722. [CrossRef] [PubMed]

22. Sharayei, P.; Azarpazhooh, E.; Zomorodi, S.; Ramaswamy, H.S. Ultrasound assisted extraction of bioactive compounds from pomegranate (Punica granatum L.) peel. LWT 2019, 101, 342-350. [CrossRef]

23. Setyaningsih, W.; Saputro, I.E.; Carrera, C.A.; Palma, M. Optimisation of an ultrasound-assisted extraction method for the simultaneous determination of phenolics in rice grains. Food Chem. 2019, 288, 221-227. [CrossRef]

24. Song, J.; Yang, Q.; Huang, W.; Xiao, Y.; Li, D.; Liu, C. Optimization of translutein from pumpkin (cucurbita moschata) peel by ultrasound-assisted extraction. Food Bioprod. Process. 2018, 107, 104-112. [CrossRef]

25. Pan, Z.; Qu, W.; Ma, H.; Atungulu, G.G.; McHugh, T.H. Continuous and pulsed ultrasound-assisted extractions of antioxidants from pomegranate peel. Ultrason. Sonochem. 2011, 18, 1249-1257. [CrossRef] [PubMed]

26. Assami, K.; Pingret, D.; Chemat, S.; Meklati, B.Y.; Chemat, F. Ultrasound induced intensification and selective extraction of essential oil from Carum carvi L. Seeds. Chem. Enginr Process. Process. Intensif. 2012, 62, 99-105. [CrossRef]

27. Jacotet-navarro, M.; Rombaut, N.; Fabiano-Tixier, A.-S.; Danguien, M.; Bily, A.; Chemat, F. Ultrasound versus microwave as green processes for extraction of rosmarinic, carnosic and ursolic acids from rosemary. Ultrason. Sonochem. 2015, 27, 102-109. [CrossRef]

28. Sereshti, H.; Heidari, R.; Samadi, S. Determination of volatile components of saffron by optimised ultrasound-assisted extraction in tandem with dispersive liquid-liquid microextraction followed by gas chromatography-mass spectrometry. Food Chem. 2014, 143, 499-505. [CrossRef] [PubMed] 
29. Hossain, M.B.; Brunton, N.P.; Patras, A.; Tiwari, B.; O’Donnell, C.P.; Martin-Diana, A.B.; Barry-Ryan, C. Optimization of ultrasound assisted extraction of antioxidant compounds from marjoram (Origanum majorana L.) Using response surface methodology. Ultrason. Sonochem. 2012, 19, 582-590. [CrossRef]

30. Kaderides, K.; Papaoikonomou, L.; Serafim, M.; Goula, A.M. Microwave-assisted extraction of phenolics from pomegranate peels: Optimization, kinetics, and comparison with ultrasounds extraction. Chem. Eng. Process. Process. Intensif. 2019, 137, 1-11. [CrossRef]

31. Pettinato, M.; Casazza, A.A.; Perego, P. The role of heating step in microwave-assisted extraction of polyphenols from spent coffee grounds. Food Bioprod. Process. 2019, 114, 227-234. [CrossRef]

32. Pimentel-Moral, S.; Borrás-Linares, I.; Lozano-Sánchez, J.; Arráez-Román, D.; Martínez-Férez, A.; Segura-Carretero, A. Microwaveassisted extraction for hibiscus sabdariffa bioactive compounds. J. Pharm. Biomed. Anal. 2018, 156, 313-322. [CrossRef]

33. Rodsamran, P.; Sothornvit, R. Extraction of phenolic compounds from lime peel waste using ultrasonic-assisted and microwaveassisted extractions. Food Biosci. 2019, 28, 66-73. [CrossRef]

34. Vinatoru, M.; Mason, T.J.; Calinescu, I. Ultrasonically assisted extraction (uae) and microwave assisted extraction (mae) of functional compounds from plant materials. TrAC Trends Anal. Chem. 2017, 97, 159-178. [CrossRef]

35. Mandal, V.; Mohan, Y.; Hemalatha, S. Microwave assisted extraction-An innovative and promising extraction tool for medicinal plant research. Pharmacogn. Rev. 2007,1,7-18.

36. Chan, C.-H.; Yusoff, R.; Ngoh, G.-C.; Kung, F.W.-L. Microwave-assisted extractions of active ingredients from plants. J. Chromatogr. 2011, 1218, 6213-6225. [CrossRef] [PubMed]

37. Wang, L.; Weller, C.L. Recent advances in extraction of nutraceuticals from plants. Trends Food Sci. Technol. 2006, 17, 300-312. [CrossRef]

38. Ajila, C.M.; Brar, S.K.; Verna, M.; Tyagi, R.D.; Valero, J.R. Solid-state fermentation of apple pomace using phanerocheate chrysosporium-Liberation and extraction of phenolic antioxidants. Food Chem. 2011, 126, 1071-1080. [CrossRef]

39. Shu, Y.Y.; Ko, M.Y.; Chang, Y.S. Microwave-assisted extraction of ginsenosides from ginseng root. Microchem. J. 2003, 74, 131-139. [CrossRef]

40. Dhobi, M.; Mandal, V.; Hemalatha, S. Optimization of microwave assisted extraction of bioactive flavonolignan-silybinin. J. Chem. Metrol. 2009, 3, 13.

41. Asghari, J.; Ondruschka, B.; Mazaheritehrani, M. Extraction of bioactive chemical compounds from the medicinal asian plants by microwave irradiation. J. Med. Plants Res. 2011, 5, 495-506.

42. Puri, M.; Sharma, D.; Barrow, C.J. Enzyme-assisted extraction of bioactives from plants. Trends Biotechnol. 2012, 30, 37-44. [CrossRef]

43. Laroze, L.; Soto, C.; Zúñiga, M.E. Phenolic antioxidants extraction from raspberry wastes assisted by-enzymes. Electron. J. Biotechnol. 2010, 13, 11-12. [CrossRef]

44. Gómez-García, R.; Martínez-Avila, G.C.G.; Aguilar, C.N. Enzyme-assisted extraction of antioxidative phenolics from grape (Vitis vinifera L.) Residues. Biotechnology 2012, 2, 297-300. [CrossRef]

45. Zhu, Z.; Li, S.; He, J.; Thirumdas, R.; Montesano, D.; Barba, F.J. Enzyme-assisted extraction of polyphenol from edible lotus (nelumbo nucifera) rhizome knot: Ultra-filtration performance and hplc-ms2 profile. Food Res. Int. 2018, 111, 291-298. [CrossRef]

46. Nadar, S.S.; Rao, P.; Rathod, V.K. Enzyme assisted extraction of biomolecules as an approach to novel extraction technology: A review. Food Res. Inter. 2018, 108, 309-330. [CrossRef] [PubMed]

47. de Moura, J.M.L.N.; Campbell, K.; Mahfuz, A.; Jung, S.; Glatz, C.E.; Johnson, L. Enzyme-assisted aqueous extraction of oil and protein from soybeans and cream de-emulsification. J. Am. Oil Chem. Soc. 2008, 85, 985-995. [CrossRef]

48. Dominguez, H.; Nunez, M.; Lema, J.M. Enzyme-assisted hexane extraction of soya bean oil. Food Chem. 1995, 54, 223-231. [CrossRef]

49. Marathe, S.J.; Jadhav, S.B.; Bankar, S.B.; Dubey, K.K.; Singhal, R.S. Improvements in the extraction of bioactive compounds by enzymes. Curr. Opin. Food Sci. 2019, 25, 62-72. [CrossRef]

50. Choudhari, S.M.; Ananthanarayan, L. Enzyme aided extraction of lycopene from tomato tissues. Food Chem. 2007, 102, 77-81. [CrossRef]

51. Passos, C.P.; Yilmaz, S.; Silva, C.M.; Coimbra, M.A. Enhancement of grape seed oil extraction using a cell wall degrading enzyme cocktail. Food Chem. 2009, 115, 48-53. [CrossRef]

52. Haider, W.; Sultana, B.; Mushtaq, M.; Bhatti, I.A. Multi-response optimization of enzyme-assisted maceration to enhance the yield and antioxidant activity of cassia fistula pods extracts. J. Food Meas. Charact. 2018, 12, 2685-2694. [CrossRef]

53. Oh, M.J.; Lee, J.; Seo, S.; Yoon, S.; Seo, M.; Park, S.; Kim, H.-S.; Ha, D.-W.; Lee, S.; Jo, Y.J. Vortex pinning in artificially layered ba(fe,co)2as2 film. Cryogenics 2018, 92, 1-4. [CrossRef]

54. Eduardo, P.; Iñigo, M.d.M. Olive oil pilot-production assisted by pulsed electric field: Impact on extraction yield, chemical parameters and sensory properties. Food Chem. 2015, 167, 497-502.

55. Rastogi, N.K. Application of high-intensity pulsed electrical fields in food processing. Food Rev. Int. 2003, 19, 229-251. [CrossRef]

56. Knoor, D.; Geulen, M.; Grahl, T.; Sitzmann, W. Food application of high electric field pulses. Trends Food Sci. Technol. 1994, 5, 71-75. [CrossRef] 
57. Barbosa, H.M.A.; de Melo, M.M.R.; Coimbra, M.A.; Passos, C.P.; Silva, C.M. Optimization of the supercritical fluid coextraction of oil and diterpenes from spent coffee grounds using experimental design and response surface methodology. J. Supercrit. Fluids 2014, 85, 165-172. [CrossRef]

58. Brunner, G. Supercritical gases as solvents: Phase equilibria. In Gas Extraction; Springer: Berlin/Heidelberg, Germany, 1994; pp. $59-146$.

59. Jesus, S.P.; Calheiros, M.N.; Hense, H.; Meireles, M.A.A. A simplified model to describe the kinetic behavior of supercritical fluid extraction from a rice bran oil byproduct. Food Public Health 2013, 3, 215-222. [CrossRef]

60. Mezzomo, N.; Martínez, J.; Ferreira, S.R. Supercritical fluid extraction of peach (prunus persica) almond oil: Kinetics, mathematical modeling and scale-up. J. Supercrit. Fluids 2009, 51, 10-16. [CrossRef]

61. Minozzo, M.; Popiolski, A.; Prá, V.D.; Treichel, H.; Cansian, R.L.; Oliveira, J.V.; Mossi, A.; Mazutti, M.A. Modeling of the overal kinetic extraction from maytenus aquifolia using compressed $\mathrm{CO}_{2}$, braz. J. Chem. Eng. 2012, 29, 835-843.

62. Rui da Silva, R.P.; Rocha-Santos, T.A.P.; Duarte, A.C. Supercritical fluid extraction of bioactive compounds. TrAC Trends Anal. Chem. 2016, 76, 40-51. [CrossRef]

63. Mesomo, M.C.; Corazza, M.L.; Ndiaye, P.; Santa, O.R.D.; Cardozo, L.; Scheer, A.D.P. Supercritical CO 2 extracts and essential oil of ginger (zingiber officinale r.): Chemical composition and antibacterial activity. J. Supercrit. Fluids 2013, 80, 44-49. [CrossRef]

64. Lindy, J. Supercritical Fluid Extraction (Technology, Applications and Limitations); Nova Science: New York, NY, USA, 2014.

65. Sovilj, M.N.; Nikolovski, B.G.; Spasojević, M.Đ. Critical review of supercritical fluid extraction of selected spice plant materials. Maced. J. Chem. Chem. Eng. 2011, 30, 197-220. [CrossRef]

66. Joo, C.G.; Lee, K.H.; Park, C.; Joo, I.W.; Choe, T.B.; Lee, B.C. Correlation of increased antioxidation with the phenolic compound and amino acids contents of camellia sinensis leaf extracts following ultra-high pressure extraction. J. Ind. Eng. Chem 2012, 18, 623-628. [CrossRef]

67. Xi, J.; Wang, B.S. Optimization of ultrahigh-pressure extraction of polyphenolic antioxidants from green tea by response surface methodology. Food Bioprocess Technol. 2013, 6, 2538-2546. [CrossRef]

68. Lee, H.S.; Lee, H.J.; Yu, H.J.; Ju, D.W.; Kim, Y.; Kim, C.-T.; Kim, C.-J.; Cho, Y.-J.; Kim, N.; Choi, S.-Y.; et al. A comparison between high hydrostatic pressure extraction and heat extraction of ginsenosides from ginseng (panax ginseng ca meyer). J. Sci. Food Agric. 2011, 8, 1466-1473. [CrossRef] [PubMed]

69. Zhang, S.T.; Wang, Z.Y.; Cheng, C.H.; Wang, T.S.; Ni, Z.; Lin, J.M. Optimization for ultra-high pressure extraction of scutellaria barbata by central composite designresponse surface methodology. Afr. J. Biotechnol. 2011, 10, 14637-14643.

70. Chen, R.; Meng, F.; Zhang, S.; Liu, Z. Effects of ultrahigh pressure extraction conditions on yields and antioxidant activity of ginsenoside from ginseng. Sep. Purif. Technol. 2009, 66, 340-346. [CrossRef]

71. Xi, J.; Shen, D.J.; Ye, L.; Rui, Z. Micromechanism of ultrahigh pressure extraction of active ingredients from green tea leaves. Food Control. 2011, 22, 1473-1476.

72. Knorr, D. Process assessment of high pressure processing of foods: An overview. In Processing Foods: Quality Optimisation and Process Assessment; Oliveira, F.A.R., Oliveira Jorge, C., Eds.; CRC Press: Boca Raton, FL, USA, 1999; pp. $249-267$.

73. Sanchez-Moreno, C.; Plaza, L. Effect of combined treatments of high-pressure and natural additives on carotenoid extractability and antioxidant activity of tomato puree (Lycopersicum esculentum mill.). Eur. Food Res. Technol. 2004, 219, 151-160. [CrossRef]

74. Prasad, K.N.; Yang, B.; Zhao, M.; Wei, X.; Jiang, Y.; Chen, F. High pressure extraction of corilagin from longan (Dimocarpus longan Lour.) Fruit Pericarp. Sep. Purif Technol. 2009, 70, 41-45. [CrossRef]

75. Zhang, S.T.; Wang, Z.Y.; Wang, T.S.; Zheng, N. Optimization of central composite design-response surface methodology in ultra-high pressure extraction of scutellaria baicalensis. J. Medicina. Plant. Res. 2012, 6, 373-378.

76. Liu, F.; Wang, D.; Liu, W.; Wang, X.; Bai, A.; Huang, L. Ionic liquid-based ultrahigh pressure extraction of five tanshinones from salvia miltiorrhiza bunge. Sep. Purif. Technol. 2013, 110, 86-92. [CrossRef]

77. Xi, J.; Zhao, S.; Lu, B.; Zhang, R.; Li, Y.; Shen, D.; Zhou, G. Separation of major catechins from green tea by ultrahigh pressure extraction. Int. J. Pharmaceut. 2010, 386, 229-231.

78. Corrales, M.; García, A.F.; Butz, P.; Tauscher, B. Extraction of anthocyanins from grape skins assisted by high hydrostatic pressure. J. Food Eng. 2009, 90, 415-421. [CrossRef]

79. Rastogi, N.K.; Raghavarao, K.S.M.S.; Balasubramaniam, V.; Niranjan, K.; Knorr, D. Opportunities and challenges in high pressure processing of foods. Crit. Rev. Food Sci. Nutri. 2007, 47, 69-112. [CrossRef]

80. Khan, S.A.; Aslam, R.; Makroo, H.A. High pressure extraction and its application in the extraction of bioactive coumounds: A review. J. Food Process. Engr. 2018, 42, e12896. [CrossRef]

81. Zhang, S.; Xi, J.; Wang, C. High hydrostatic pressure extraction of flavonoids from propolis. J. Chem. Technol. Biot. 2005, 80, 50-54.

82. Le Noble, W.J. Organic High Pressure Chemistry; Elsevier: Amsterdam, The Netherlands, 1988; Volume 37, 489p.

83. Richard, J.S. High Pressure Phase Behaviour of Multicomponent Fluid Mixtures; Elsevier: Amsterdam, The Netherlands, 1992.

84. Ganeva, V.; Galutzov, B. Electropulsation as an alternative method for protein extraction from yeast. Fems. Microbiol. Lett. 1999, 174, 279-284. [CrossRef] [PubMed] 
85. Yin, Y.; Cui, Y.; Ding, H. Optimization of betulin extraction process from inonotus obliquus with pulsed electric fields. Innov. Food Sci. Emerg. 2008, 9, 306-310. [CrossRef]

86. Luo, X.; Bai, R.; Zhen, D.; Yang, Z.; Huang, D.; Mao, H.; Li, X.; Zou, H.; Xiang, Y.; Liu, K.; et al. Response surface optimization of the enzyme-based ultrasound-assisted extraction of acorn tannins and their corrosion inhibition properties. Ind. Crop. Prod. 2019, 129, 405-413. [CrossRef]

87. Chen, F.; Zhang, Q.; Gu, H.; Yang, L. An approach for extraction of kernel oil from pinus pumila using homogenate-circulating ultrasound in combination with an aqueous enzymatic process and evaluation of its antioxidant activity. J. Chromatogr. A 2016, 1471, 68-79. [CrossRef]

88. Amiri-rigi, A.; Abbasi, S.; Scanlon, M.G. Enhanced lycopene extraction from tomato industrial waste using microemulsion technique: Optimization of enzymatic and ultrasound pre-treatments. Innov. Food Sci. Emerg. Technol. 2016, 35, 160-167. [CrossRef]

89. Ladole, M.R.; Nair, R.R.; Bhutada, Y.D.; Amritkar, V.D.; Pandit, A.B. Synergistic effect of ultrasonication and co-immobilized enzymes on tomato peels for lycopene extraction. Ultrason. Sonochem. 2018, 48, 453-462. [CrossRef]

90. Sun, Y.; Zhang, Y.; Qi, W.; Xie, J.; Cui, X. Saponins extracted by ultrasound from zizyphus jujuba mil var. Spinosa leaves exert resistance to oxidative damage in caenorhabditis elegans. Food Meas. 2021, 15, 541-554. [CrossRef]

91. Navarro Del Hierro, J.; Herrera, T.; García-Risco, M.R.; Fornari, T.; Reglero, G.; Martin, D. Ultrasound-assisted extraction and bioaccessibility of saponins from edible seeds: Quinoa, lentil, fenugreek, soybean and lupin. Food Res. Interna. 2018, 109, 440-447. [CrossRef] [PubMed]

92. Hadidi, M.; Ibarz, A.; Pagan, J. Optimisation and kinetic study of the ultrasonic-assisted extraction of total saponins from alfalfa (medicago sativa) and its bioaccessibility using the response surface methodology. Food Chem. 2020, 309, 125786. [CrossRef]

93. Hu, T.; Guo, Y.-Y.; Zhou, Q.-F.; Zhong, X.-K.; Zhu, L.; Piao, J.-H.; Chen, J.; Jiang, J.-G. Optimization of ultrasonic-assisted extraction of total saponins from Eclipta prostrasta L. using response surface methodology. J. Food Sci. 2012, 77, 975-982. [CrossRef] [PubMed]

94. Nafiunisa, A.; Aryanti, N.; Wardhani, D.H. Kinetic study of saponin extraction from sapindus rarak dc by ultrasound-assisted extraction methods. Bull. Chem. React. Eng. Catal. 2019, 14, 468-477. [CrossRef]

95. Rohilla, S.; Mahanta, C.L. Optimization of extraction conditions for ultrasound-assisted extraction of phenolic compounds from tamarillo fruit (Solanum betaceum) using response surface methodology. Food Meas. 2021, 15, 1763-1773. [CrossRef]

96. Ali, M.C.; Chen, J.; Zhang, H.; Li, Z.; Zhao, L.; Qiu, H. Effective extraction of flavonoids from Lycium barbarum L. fruits by deep eutectic solvents-based ultrasound-assisted extraction. Talanta 2019, 203, 16-22. [CrossRef] [PubMed]

97. Upadhyay, R.; Nachiappan, G.; Mishra, H.N. Ultrasound-assisted extraction of flavonoids and phenolic compounds from Ocimum tenuiflorum leaves. Food Sci. Biotechnol. 2015, 24, 1951-1958. [CrossRef]

98. Tomšik, A.; Pavlić, B.; Vladić, J.; Ramić, M.; Brindza, J.; Vidović, S. Optimization of ultrasound-assisted extraction of bioactive compounds from wild garlic (Allium ursinum L.). Ultrason. Sonochem. 2016, 29, 502-511. [CrossRef]

99. Altemimi, A.; Watson, D.G.; Choudhary, R.; Dasari, M.R.; Lightfoot, D. Ultrasound assisted extraction of phenolic compounds from peaches and pumpkins. PLoS ONE 2016, 11, e0148758. [CrossRef]

100. Wang, X.; Wu, Y.; Chen, G.; Yue, W.; Liang, Q.; Wu, Q. Optimisation of ultrasound assisted extraction of phenolic compounds from Sparganii rhizoma with response surface methodology. Ultrason. Sonochem. 2013, 20, 846-854. [CrossRef] [PubMed]

101. Wang, B.; Qu, J.; Luo, S.; Feng, S.; Li, T.; Yuan, M.; Huang, Y.; Liao, J.; Yang, R.; Ding, C. Optimization of ultrasound-assisted extraction of flavonoids from olive (Olea europaea) leaves, and evaluation of their antioxidant and anticancer activities. Molecules 2018, 23, 2513. [CrossRef] [PubMed]

102. Garcia-Castello, E.M.; Rodriguez-Lopez, A.D.; Mayor, L.; Ballesteros, R.; Conidi, C.; Cassano, A. Optimization of conventional and ultrasound assisted extraction of flavonoids from grapefruit (Citrus paradisi L.) solid wastes. Food Sci. Technol. 2015, 64, 1114-1122. [CrossRef]

103. Ramli, N.H.; Yusup, S.; Quitain, A.T.; Johari, K.; Bin Kueh, B.W. Optimization of saponin extracts using microwave-assisted extraction as a sustainable biopesticide to reduce pomacea canaliculata population in paddy cultivation. Sustain. Chem. Pharm. 2019, 11, 23-35. [CrossRef]

104. Gao, W.; Chen, F.; Li, H.; Wang, X.; Meng, Q. Microwave-assisted extraction of total saponins from Physalis alkekengi L. var. Franchetii (mast.) Makino and their in vitro anti-inflammatory activity. Food Meas. 2019, 13, 2921-2934. [CrossRef]

105. Dahmoune, B.; Houma-Bachari, F. Microwave assisted extraction of bioactive saponins from the starfish echinaster sepositus: Optimization by response surface methodology and comparison with ultrasound and conventional solvent extraction. Chem. Eng. Process. Process. Intensif. 2021, 163, 108359. [CrossRef]

106. Nguyen, V.T.; Bowyer, M.C.; Van Altena, I.A.; Scarlett, C.J. Microwave-assisted extraction as an advanced technique for optimization of saponin yield and antioxidant potential from phyllanthus amarus. Sep. Sci. Technol. 2017, 52, 1-11. [CrossRef]

107. Tian, Y.; Zhao, H. Comparison of different extraction techniques and optimization of the microwave-assisted extraction of saponins from aralia elata (miq.) Seem fruits and rachises. Chem. Pap. 2020, 74, 3077-3087. [CrossRef] 
108. Le, A.V.; Parks, S.E.; Nguyen, M.H.; Roach, P.D. Optimisation of the microwave-assisted ethanol extraction of saponins from gac (momordica cochinchinensis spreng.) Seeds. Medicines 2018, 5, 70. [CrossRef]

109. Chen, Y.; Xie, M.-Y.; Gong, X.-F. Microwave-assisted extraction used for the isolation of total triterpenoid saponins from ganoderma atrum. J. Food Engr. 2007, 81, 162-170. [CrossRef]

110. Kwon, J.-H.; Lee, G.-D.; Bélanger, J.M.R.; Paré, J.R.J. Effect of ethanol concentration on the efficiency of extraction of ginseng saponins when using a microwave-assisted process (maptm). Int. J. Food Sci. Technol. 2003, 38, 615-622. [CrossRef]

111. Nguyen, V.T.; Le, M.D.; Nguyen, T.T.T.; Khong, T.T.; Nguyen, H.N.; Huynh, B.N.D.; Tran, H.T.M.; Trang, T.S. Microwave-assisted extraction for optimizing saponin yield and antioxidant capacity from cacao pod husk (Theobroma cacao L.). J. Food Process. Preserv. 2021, 45, e15134. [CrossRef]

112. Nguyen, V.T.; Vuong, Q.V.; Bowyer, M.C.; Van Altena, I.A.; Scarlett, C.J. Microwave-assisted extraction for saponins and antioxidant capacity from xao tam phan (paramignya trimera) root. J. Food Process. Preserv. 2016, 41, e12851. [CrossRef]

113. Zheng, X.; Xu, X.; Liu, C.; Sun, Y.; Lin, Z.; Liu, H. Extraction characteristics and optimal parameters of anthocyanin from blueberry powder under microwave-assisted extraction conditions. Sep. Purif. Technol. 2013, 104, 17-25. [CrossRef]

114. Yang, Z.; Zhai, W. Optimization of microwave-assisted extraction of anthocyanins from purple corn (Zea mays L.) cob and identification with HPLC-MS. Innov. Food Sci. Emerg. Technol. 2010, 11, 470-476. [CrossRef]

115. Zhang, F.; Yang, Y.; Su, P.; Guo, Z. Microwave-assisted extraction of rutin and quercetin from the stalks of Euonymus alatus (Thunb.) sieb. Phytochem. Anal. 2008, 20, 33-37. [CrossRef] [PubMed]

116. Yen, N.T.; Quoc, L.P. Chemical composition and cellulase-assisted extraction of total saponins from gomphrena celosioides mart. Biotechnologia 2020, 101, 361-367. [CrossRef]

117. Huy, T.B.; Phuong, N.T.L.; Nga, B.K.; Oanh, H.N.; Hieu, N.H. Enzyme-assisted extraction of triterpenoid saponins from pseuderanthemum palatiferum (nees) radlk. Dry leaf powder and bioactivities examination of extracts. Chem. Sel. 2019, 4 , 8129-8134. [CrossRef]

118. Tomaz, I.; Maslov, L.; Stupić, D.; Preiner, D.; Ašperger, D.; Kontić, J.K. Recovery of flavonoids from grape skins by enzyme-assisted extraction. Sep. Sci. Technol. 2016, 51, 255-268. [CrossRef]

119. Boulila, A.; Hassen, I.; Haouari, L.; Mejri, F.; Ben Amor, I.; Casabianca, H.; Hosni, K. Enzyme-assisted extraction of bioactive compounds from bay leaves (Laurus nobilis L.). Ind. Crop. Prod. 2015, 74, 485-493. [CrossRef]

120. Abhari, H.; Rad, A.H.; Abhari, A.; Karajian, H. Extracting of saponin from acanthophyllum roots using pulsed electric field (pef) pretreatment and comparing it with thermal method and studying of its antioxidant and foaming properties. J. Biochem. Technol. 2018, 2, 166-176.

121. Ji, H.; Zhang, L.; Li, J.; Yang, M.; Liu, X. Optimization of ultrahigh pressure extraction of momordicosides from bitter melon. Int. J. Food Eng. 2010, 6. [CrossRef]

122. Wang, Q.-Y.; Dong, X. Vesicle based ultrasonic-assisted extraction of saponins in panax notoginseng. Food Chem. 2020, 303, 125394. [CrossRef]

123. Kai, T.; Jie, Y.; Xin, H. A technological research on synergetic extraction of Momordica charantia L. Saponin using microwavesurfactant. Appl. Mech. Mater. 2014, 563, 384-390. [CrossRef]

124. Lu, C.-W.; Yin, Y.-G.; Yu, Q. Optimized extraction of ginsenosides from ginseng root (panax ginsengc.a. meyer) by pulsed electric field combined with commercial enzyme. J. Food Process. Preserva. 2016, 41, e12766. [CrossRef]

125. Tzima, K.; Brunton, N.P.; Lyng, J.G.; Frontuto, D.; Rai, D.K. The effect of pulsed electric field as a pre-treatment step in ultrasound assisted extraction of phenolic compounds from fresh rosemary and thyme by-products. Innov. Food Sci. Emerg. Technol. 2021, 69, 102644. [CrossRef]

126. Sunwoo, H.H.; Gujral, N.; Huebl, A.C.; Kim, C.-T. Application of high hydrostatic pressure and enzymatic hydrolysis for the extraction of ginsenosides from fresh ginseng root (panax ginseng c.a. myer). Food Bioprocess. Techn. 2013, 7, 1246-1254. [CrossRef]

127. Machado, A.P.D.F.; Reátegui, J.L.P.; Barbero, G.F.; Martínez, J. Pressurized liquid extraction of bioactive compounds from blackberry (Rubus fruticosus L.) residues: A comparison with methods. Food Res. Int. 2015, 77, 675-683. [CrossRef]

128. Kiss, E. Nano-technology in food systems: A review. Acta Aliment. 2020, 49, 460-474. [CrossRef]

129. Shimoni, E. Nano-technology for foods: Delivery systems. Glob. Issues Food Sci. Technol. 2009, 411-424. [CrossRef]

130. Liu, T.; Liu, L.; Gong, X.; Chi, F.; Ma, Z. Fabrication and comparison of active films from chitosan incorporating different spice extracts for shelf life extension of refrigerated pork. LWT 2021, 135, 110181. [CrossRef]

131. Katouzian, I.; Jafari, S.M. Nano-encapsulation as a promising approach for targeted delivery and controlled release of vitamin. Trends Food Sci. Technol. 2016, 53, 34-48. [CrossRef]

132. Ravi, H.; Kurrey, N.; Manabe, Y.; Sugawara, T.; Baskaran, V. Polymeric chitosan-glycolipid nano-carriers for an effective delivery of marine carotenoid fucoxanthin for induction of apoptosis in human colon cancer cells (caco-2 cells). Mater. Sci. Engr. 2018, 91, 785-795. [CrossRef]

133. Gagliardi, A.; Paolino, D.; Costa, N.; Fresta, M.; Cosco, D. Zein- vs plga-based nano-particles containing rutin: A comparative investigation. Mater. Sci. Eng. C 2020, 118, 111538. [CrossRef] [PubMed]

134. Costa, J.R.; Xavier, M.; Amado, I.R.; Gonçalves, C.; Castro, P.M.; Tonon, R.V.; Cabral, L.M.; Pastrana, L.; Pintado, M.E. Polymeric nano-particles as oral delivery systems for a grape pomace extract towards the improvement of biological activities. Mater. Sci. Eng. C 2021, 119, 111551. [CrossRef] [PubMed] 
135. Zare, M.; Norouzi Roshan, Z.; Assadpour, E.; Jafari, S.M. Improving the cancer prevention/treatment role of carotenoids through various nano-delivery systems. Crit. Rev. Food Sci. Nutr. 2020, 61, 1-13. [CrossRef] [PubMed]

136. Seyedabadi, M.M.; Rostami, H.; Jafari, S.M.; Fathi, M. Development and characterization of chitosan-coated nano-liposomes for encapsulation of caffeine. Food Biosci. 2021, 40, 100857. [CrossRef]

137. Assadpour, E.; Jafari, S.M. Nano-encapsulation: Techniques and developments for food applications. Nano Mater. Food Appl. 2019, 35-61. [CrossRef]

138. Chaudhari, A.K.; Singh, V.K.; Das, S.; Dubey, N.K. Nano-encapsulation of essential oils and their bioactive constituents: A novel strategy to control mycotoxin contamination in food system. Food Chem. Toxicol. 2021, 149, 112019. [CrossRef] [PubMed]

139. Abd-Elhakeem, E.; El-Nabarawi, M.; Shamma, R. Lipidbased nano-formulation platform for eplerenone oral delivery as a potential treatment of chronic central serous chorioretinopathy: In-vitro optimization and ex-vivo assessment. Drug Deliv. 2021, 28, 642-654. [CrossRef]

140. Bhushani, J.A.; Kurrey, N.K.; Anandharamakrishnan, C. Nano-encapsulation of green tea catechins by electrospraying technique and its effect on controlled release and in-vitro permeability. J. Food Engr. 2017, 199, 82-92. [CrossRef]

141. Ghorani, B.; Tucker, N. Fundamentals of electrospinning as a novel delivery vehicle for bioactive compounds in food nanotechnology. Food Hydrocoll. 2015, 51, 227-240. [CrossRef]

142. Torres-Giner, S.; Perez-Masia, R.; Lagaron, J.M. A review on electrospun polymer nano-structures as advanced bioactive platforms. Polym. Engr. Sci. 2016, 56, 500-527. [CrossRef]

143. Zhang, C.; Zhang, H. Formation and stability of core-shell nano-fibers by electrospinning of gel-like corn oil-in-water emulsions stabilized by gelatin. J. Agri. Food Chem. 2018, 66, 11681-11690. [CrossRef]

144. Vyslouzilova, L.; Buzgo, M.; Pokorný, P.; Chvojka, J.; Míčková, A.; Rampichová, M.; Kula, J.; Pejchar, K.; Bilek, M.; Lukáš, D.; et al. Needleless coaxial electrospinning: A novel approach to mass production of coaxial nano-fibers. Int. J. Pharm. 2017, 516, 293-300. [CrossRef]

145. Kutzli, I.; Gibis, M. Formation of whey protein isolate (WPI)-maltodextrin conjugates in fibers produced by needleless electrospinning. J. Agric. Food Chem. 2018, 66, 10283-10291. [CrossRef] [PubMed]

146. Xiao, Q.; Lim, L.-T. Pullulan-alginate fibers produced using free surface electrospinning. Int. J. Biol. Macromol. 2018, 112, 809-817. [CrossRef]

147. Moreira, J.B.; Lim, L.-T. Microalgae protein heating in acid/basic solution for nano-fibers production by free surface electrospinning. J. Food Eng. 2018, 230, 49-54. [CrossRef]

148. Poornima, B.; Korrapati, P.S. Fabrication of chitosan-polycaprolactone composite nano-fibrous scaffold for simultaneous delivery of ferulic acid and resveratrol. Carbohydr. Polym. 2017, 157, 1741-1749. [CrossRef] [PubMed]

149. Leena, M.; Yoha, K.S. Edible coating with resveratrol loaded electrospun zein nano-fibers with enhanced bioaccessibility. Food Biosci. 2020, 36, 100669. [CrossRef]

150. Jayan, H.; Maria Leena, M.; Sundari, S.S.; Moses, J.; Anandharamakrishnan, C. Improvement of bioavailability for resveratrol through encapsulation in zein using electrospraying technique. J. Funct. Foods 2019, 57, 417-424. [CrossRef]

151. Maa, Y.-F.; Nguyen, P.-A.; Sit, K.; Hsu, C.C. Spray-drying performance of a bench-top spray dryer for protein aerosol powder preparation. Biotech. Bioengr. 2000, 60, 301-309. [CrossRef]

152. Adel, I.M.; ElMeligy, M.F.; Abdelrahim, M.E.; Maged, A.; Abdelkhalek, A.A.; Abdelmoteleb, A.M.; Elkasabgy, N.A. Design and characterization of spray-dried proliposomes for the pulmonary delivery of curcumin. Int. J. Nano Med. 2021, 16, $2667-2687$. [CrossRef] [PubMed]

153. Mozaffar, S.; Radi, M. A new approach for drying of nano-structured lipid carriers (NLC) by spray-drying and using sodium chloride as the excipient. J. Drug Deliv. Sci. Technol. 2021, 61, 102212. [CrossRef]

154. Datta, S.S.; Abbaspourrad, A.; Amstad, E.; Fan, J.; Kim, S.-H.; Romanowsky, M.; Shum, H.C.; Sun, B.; Utada, A.S.; Windbergs, M.; et al. 25th anniversary article: Double emulsion templated solid microcapsules: Mechanics and controlled release. Adv. Mater. 2014, 26, 2205-2218. [CrossRef]

155. Jafari, S.M.; He, Y.; Bhandari, B. Optimization of nano-emulsions production by microfluidization. Eur. Food Res. Technol. 2007, 225, 733-741. [CrossRef]

156. Wang, S.; Ye, X.; Sun, Y.; Liang, J.; Yue, P.; Gao, X. Nano-complexes derived from chitosan and whey protein isolate enhance the thermal stability and slow the release of anthocyanins in simulated digestion and prepared instant coffee. Food Chem. 2021, 336, 127707. [CrossRef] [PubMed]

157. Donsi, F.; Ferrari, G.; Maresca, P. High-pressure homogenization for food sanitization. Glob. Issues Food Sci. Technol. 2009, 309-352. [CrossRef]

158. Georget, E.; Miller, B.; Aganovic, K.; Callanan, M.; Heinz, V.; Mathys, A. Bacterial spore inactivation by ultra-high pressure homogenization. Innov. Food Sci. Emerg. Technol. 2014, 26, 116-123. [CrossRef]

159. Fernandez-Avila, C.; Trujillo, A. Ultra-high pressure homogenization improves oxidative stability and interfacial properties of soy protein isolate stabilized emulsions. Food Chem. 2016, 209, 104-113. [CrossRef]

160. Lorimer, J.P.; Mason, T.J. Sonochemistry. Part 1-The physical aspects. Chem. Soc. Rev. 1987, 16, 239-274. [CrossRef]

161. Bermudez-Aguirre, D.; Mobbs, T.; Barbosa-Cánovas, G.V. Ultrasound Applications in Food Processing; Springer: New York, NY, USA, 2011; pp. 65-105. [CrossRef] 
162. Rafiee, Z.; Nejatian, M.; Daeihamed, M.; Jafari, S.M. Application of different nano-carriers for encapsulation of curcumin. Crit. Rev. Food Sci. Nutr. 2019, 59, 1-77. [CrossRef] [PubMed]

163. Rezaei, A.; Fathi, M.; Jafari, S.M. Nano-encapsulation of hydrophobic and low- soluble food bioactive compounds within different nano-carriers. Food Hydrocoll. 2019, 88, 146-162. [CrossRef]

164. Rostamabadi, H.; Falsafi, S.R.; Jafari, S.M. Nano-encapsulation of carotenoids within lipid-based nano-carriers. J. Control. Release 2019, 298, 38-67. [CrossRef]

165. Thote, A.J.; Gupta, R.B. Formation of nano-particles of a hydrophilic drug using supercritical carbon dioxide and microencapsulation for sustained release. Nanomed. Nanotechnol. Biol. Med. 2005, 1, 85-90. [CrossRef] [PubMed]

166. Reverchon, E.; Adami, R. Nano-materials and supercritical fluids. J. Supercrit. Fluids 2006, 37, 1-22. [CrossRef]

167. Lee, L.Y.; Wang, C.H.; Smith, K.A. Supercritical antisolvent production of biodegradable micro- and nanoparticles for controlled delivery of paclitaxel. J. Control. Release 2008, 125, 96-106. [CrossRef]

168. Lee, L.Y.; Smith, K.A.; Wang, C.-H. Fabrication of controlled release devices for anticancer agents using supercritical antisolvent method. In Proceedings of the AIChE Annual Meeting, Cincinnati, OH, USA, 30 October-4 November 2005.

169. Zhang, Q.; Shen, Z.; Nagai, T. Prolonged hypoglycemic effect of insulin-loaded polybutylcyanoacrylate nano-particles after pulmonary administration to normal rats. Int. J. Pharm. 2001, 218, 75-80. [CrossRef]

170. Boudad, H.; Legrand, P.; Lebas, G.; Cheron, M.; Duchêne, D.; Ponchel, G. Combined hydroxypropyl-[beta]- cyclodextrin and poly(alkylcyanoacrylate) nano-particles intended for oral administration of saquinavir. Int. J. Pharm. 2001, 218, 113-124. [CrossRef]

171. Calvo, P.; Remunan-Lopez, C.; Vila-Jato, J.L.; Alonso, M.J. Chitosan and chitosan/ethylene oxide-propylene oxide block copolymer nano-particles as novel carriers for proteins and vaccines. Pharm. Res. 1997, 14, 1431-1436. [CrossRef]

172. Panyam, J.; Labhasetwar, V. Biodegradable nano-particles for drug and gene delivery to cells and tissue. Adv. Drug Deliv Rev. 2003, 55, 329-347. [CrossRef]

173. Desai, M.P.; Labhasetwar, V.; Walter, E.; Levy, R.J.; Amidon, G.L. The mechanism of uptake of biodegradable microparticles in Caco-2 cells is size dependent. Pharm. Res. 1997, 14, 1568-1573. [CrossRef]

174. Alexander, M.; Dalgleish, D.G. Dynamic light scattering techniques and their applications in food science. Food Biophys. 2006, 1, 2-13. [CrossRef]

175. Couvreur, P.; Barratt, G.; Fattal, E.; Legrand, P.; Vauthier, C. Nano-capsule technology: A review. Crit. Rev. Ther. Drug Carrier Syst. 2002, 19, 99-134. [CrossRef] [PubMed]

176. Desai, M.P.; Labhasetwar, V.; Amidon, G.L.; Levy, R.J. Gastrointestinal uptake of biodegradable microparticles: Effect of particle size. Pharm. Res. 1996, 13, 1838-1845. [CrossRef] [PubMed]

177. Comunian, T.A.; Jafari, S.M. Production of food bioactive-loaded nano-structures by micro-/nano-fluidics. Nano Encap. Food Ingr. Speci. Equip. 2019, 3, 213-250. [CrossRef]

178. Jafari, S.M.; Assadpoor, E.; He, Y.; Bhandari, B. Encapsulation efficiency of food flavours and oils during spray drying. Drying Technol. 2008, 26, 816-835. [CrossRef]

179. Panyam, J.; Williams, D.; Dash, A.; Leslie-Pelecky, D.; Labhasetwar, V. Solid-state solubility influences encapsulation and release of hydrophobic drugs from PLGA/PLA nano-particles. J. Pharm. Sci. 2004, 93, 1804-1814. [CrossRef] [PubMed]

180. Magenheim, B.; Levy, M.Y.; Benita, S. A new in vitro technique for the evaluation of drug release profile from colloidal carriersUltrafiltration technique at low pressure. Int. J. Pharm. 1993, 94, 115-123. [CrossRef]

181. Puglisi, G.; Fresta, M.; Giammona, G.; Ventura, C.A. Influence of the preparation conditions on poly(ethylcyanoacrylate) nano-capsule formation. Int. J. Pharm. 1995, 125, 283-287. [CrossRef]

182. Cai, Z.-Y.; Li, X.-M.; Liang, J.-P.; Xiang, L.-P.; Wang, K.-R.; Shi, Y.-L.; Yang, R.; Shi, M.; Ye, J.-H.; Lu, J.-L.; et al. Bioavailability of tea catechins and its improvement. Molecules 2018, 23, 2346. [CrossRef] [PubMed]

183. Zanin, R.C.; Smrke, S.; Kurozawa, L.E.; Yamashita, F.; Yeretzian, C. Modulation of aroma release of instant coffees through microparticles of roasted coffee oil. Food Chem. 2021, 341, 128193. [CrossRef] [PubMed]

184. Rana, A.; Rana, S.; Kumar, S. Phytotherapy with active tea constituents: A review. Environ. Chem. Lett. 2021, 19, 2031-2041. [CrossRef]

185. Ahmad, M.; Mudgil, M.; Gani, A.; Hamed, F.; Masoodi, F.A.; Maqsood, S. Nano-encapsulation of catechin in starch nanoparticles: Characterization; release behavior and bioactivity retention during in-vitro digestion. Food Chem. 2019, 270, 95-104. [CrossRef] [PubMed]

186. Rojas-Graü, M.A.; Soliva-Fortuny, R.; Martín-Belloso, O. Effect of natural antibrowning agents on color and related enzymes in fresh-cut fuji apples as an alternative to the use of ascorbic acid. J. Food Sci. 2008, 73, 267-672. [CrossRef]

187. Zheng, Z.-P.; Cheng, K.-W.; To, J.T.-K.; Li, H.; Wang, M. Isolation of tyrosinase inhibitors from Artocarpus heterophyllus and use of its extract as antibrowning agent. Mol. Nutr. Food Res. 2008, 52, 1530-1538. [CrossRef]

188. Tang, C.-H. Strategies to utilize naturally occurring protein architectures as nano-vehicles for hydrophobic nutraceuticals. Food Hydrocoll. 2021, 112, 106344. [CrossRef]

189. Hao, T.; Wang, K.; Zhang, S.; Yang, S.; Wang, P.; Gao, F.; Zhao, Y.; Guo, N.; Yu, P. Preparation, characterization, antioxidant evaluation of new curcumin derivatives and effects of forming HSA-bound nano-particles on the stability and activity. Eur. $J$. Med. Chem. 2020, 207, 112798. [CrossRef] [PubMed] 
190. Luo, R.; Lin, M.; Zhang, C.; Shi, J.; Zhang, S.; Chen, Q.; Hu, Y.; Zhang, M.; Zhang, J.; Gao, F. Genipin-crosslinked human serum albumin coating using a tannic acid layer for enhanced oral administration of curcumin in the treatment of ulcerative colitis. Food Chem. 2020, 330, 127241. [CrossRef]

191. Hadiya, S.; Radwan, R.; Zakaria, M.; El-Sherif, T.; Hamad, M.A.; Elsabahy, M. Nano-particles integrating natural and synthetic polymers for in vivo insulin delivery. Pharm. Dev. Technol. 2021, 26, 30-40. [CrossRef]

192. Cruz-Romero, M.; Murphy, T.V.; Morris, M.; Cummins, E.; Kerry, J. Antimicrobial activity of chitosan, organic acids and nanosized solubilisates for potential use in smart antimicrobially-active packaging for potential food applications. Food Control. 2013, 34, 393-397. [CrossRef]

193. Pan, J.; Ai, F.; Shao, P.; Chen, H.; Gao, H. Development of polyvinyl alcohol/ $\beta$-cyclodextrin antimicrobial nano-fibers for fresh mushroom packaging. Food Chem. 2019, 300, 125249. [CrossRef] [PubMed]

194. Adel, A.M.; Ibrahim, A.A.; El-Shafei, A.M.; Al-Shemy, M.T. Inclusion complex of clove oil with chitosan/ $\beta$-cyclodextrin citrate/oxidized nano-cellulose biocomposite for active food packaging. Food Packag. Shelf Life 2019, 20, 100307. [CrossRef]

195. Xiao, N.-Y.; Zhang, X.-Q.; Ma, X.-Y.; Luo, W.-H.; Li, H.-Q.; Zeng, Q.-Y.; Zhong, L.; Zhao, W.-H. Construction of EVA/chitosan based PEG-PCL micelles nano-composite films with controlled release of iprodione and its application in pre-harvest treatment of grapes. Food Chem. 2020, 331, 127277. [CrossRef] [PubMed] 